DOI: 10.20472/IAC.2019.046.001

\author{
NABA KUMAR ADAK \\ Sabang Sajanikanta Mahavidyalaya, India
}

\title{
MODERN MONEY THEORY IS A HOAX AS ITS ARGUMENTS ARE CONTRADICTORY, BASED ON IRRATIONAL PROPOSITIONS, AND IMPRACTICAL
}

\begin{abstract}
:
The purpose of this paper is to apprise the readers of the MMT's misconception misrepresentation relating origin and character of money, monetary policy, fiscal policy and to explain that these concepts and theories of MMT are hypothetical and have no connection with how present economy is functioning and that if the suggestion of MMT for increasing budget-deficit without provisioning how that deficit will be redeemed then this policy of increasing deficit heedlessly will lead the economy as a whole to a catastrophe and collapse. This is a conceptual/ theoretical paper that addresses various definitions, concepts, theories and practices that the MMT believes to be prevalent in the present economics studies and economic activities are unrealistic and their suggestions are unhelpful for smooth function of the economy. Based scholarship, I make an argument that these need to be corrected or re-addressed. Bolstered by published research in this domain, I further argue that this exercise is necessary in order to eliminate the negative effects of the MMT theories on the economy at large. The other purpose of this paper is to make suggestions about how and why money originated and how the present monetary and fiscal policies are being framed and followed and how those policies can be corrected to facilitate smooth functioning of the economy and to achieve sustainable economic growth. To make economy function properly and to make sure that the economy does not face any austerity or unemployment or ineffective production and distribution system, the faults or defects with the MMT that is gaining ground among economists should be explained clearly and conclusively so that economists do not fall in the trap of MMT's imaginary and hypothetical theory of 'functional finance' and 'a government that issues its sovereign currency can never go default'. And finally, grounded in scholarly literature, I also argue that other notions relating to monetary, fiscal and financial policies also need to be clearly understood to make those policies viable and efficient for the economy to have a balance between production and distribution.
\end{abstract}

\section{Keywords:}

functional finance, hierarchy of money, Modern Money Theory, credit theory of money, state theory of money, printing money, theory of consolidation between government and central bank, full employment, High powered money 


\section{Introduction}

"MMT is a relatively new approach that builds on the insights of John Maynard Keynes, Karl Marx, A. Mitchell Innes, George F. Knapp, Abba Lerner, Hyman Minsky, Wynne Godley, and many others - stretching back to Adam Smith and before" [like Geoffrey Ingham, J. A. Schumpeter, David Greaber, C. A. F. Goodhart, Philip Grierson, etc.]. It "stands on the shoulders of giants", as Minsky put it." [Wray June 2014, p.2]

"In recent years an approach to macroeconomics called Modern Money Theory (MMT) has been developed. In my view, it is a synthesis of several strands of heterodox-largely Post Keynesianthought. It draws heavily on the work of Georg Friedrich Knapp, A. Mitchell Innes, John Maynard Keynes, Abba Lerner, Hyman Minsky, and Wynne Godley, to integrate the state theory of money, endogenous money, functional finance, financial instability hypothesis, and sectoral balance approaches. I would characterize it the way that Minsky (1977) characterized his own attempt at a synthesis: it "stands on the shoulders of giants."' [Wray Jan. 2018, P2] L. Randall Wray is the leading MMT Economist. Lagu Randall Wray is a Senior Research Associate for Full Employment and Price Stability, University of Missouri-Kansas City, and Senior Scholar, Jerome Levy Economics Institute. He asserts that, "we began creating what came to be called MMT". [Wray Jan. 2018, P2]. Since 1980s, other prominent economists those are working on MMT are Warren Mosler, Bill Mitchell, Jan Kregel, Stephanie Kelton Bell, Pavlina Tcherneva, Mathew Forstater, Ed Nell, Scott Fullwiler, Eric Tymoigne, Joelle LeClaire, Heather Starzinsky, Daniel Conceicao, Felipe Rezende, Flavia Dantas, Yan Liang, Fadhel Kaboub, Zdravka Todorova, Andy Felkerson, Nicola Matthews, Shakuntala Das, Corinne Pastoret, Mike Murray, Alla Semenova, Yeva Nersisyan, Dimitri Papadimitriou, Maurice Sammuels, Cliff Viner, and Scott Ramsey etc.

"Its [MMT's] research has stretched across the sub-disciplines of economics, including history of thought, economic history, monetary theory, unemployment and poverty, finance and financial institutions, sectoral balances, cycles and crises, and monetary and fiscal policy. It has largely updated and synthesized various strands of theory, most of it heterodox-outside the mainstream." [Wray June 2014, p-2] "MMT reaches conclusions that are shocking to many who've been indoctrinated in the conventional wisdom. Most importantly, it challenges the orthodox views about government finance, monetary policy, the so-called Phillips Curve (inflation-unemployment) trade-off, the wisdom of fixed exchange rates, and the folly of striving for current account surpluses." [Wray June 2014, p-3]

However, MMT has neither ushered any new policy formulation, nor has it modified the existing monetary and fiscal system. It fails to define money. According to the MMT never there was money; exchanges have been being done only through each other's monetary instruments called IOUs. It is a futile effort of combining wrong propositions made by earlier economists. In the literature survey, I will enumerate and cite the basic theories and propositions that the MMT made. Next, I will assess them separately and show why they are irrational, contradictory and impractical. I will discuss briefly some important theoretical postulations of MMT regarding credit (debt) theory of money, state theory of money, hierarchy of money, taxes and bonds, Functional finance, theory of consolidation between the central bank and the government, and theory of government as the employer of last resort.

Modern Money Theory is a conglomeration of different contradictory and impractical theories put forward by earlier economists. The theories that the MMT uses to develop its own theory are: 
Credit theory of Innes, State theory or chartalist theory of money of Georg Friedrich Knapp, (Ingham combined credit theory and state theory of money in his article "Money is a Social Relation), functional finance theory of Lerner, Money theory of Keynes. The MMT develops a new theory called consolidation between the government and the central bank theory. Thus, the MMT integrates all those theories that are obsolete and full of contradictions and un-intelligible ones with some additions of their own. Therefore, the MMT (as it is based on wrong theories) became a hotchpotch contributing, to the understanding of the nature of money, monetary policy and fiscal policy, a theory that is beyond conceivability and very much unrealistic and at all not functional.

In the Credit theory of Money, money by nature, according to MMT, is a monetary (debt) instrument and not a medium of exchange and deriving its value not from its intrinsic commoditycontent value but from the declaration of its issuing authority (government) regarding what value each unit of money will bear; it is nothing but a numeraire (just the number of units of government's debt written on it). In the state theory, money is, according to MMT (as Keynes put it), what the states issues, denominates and spends and forces the taxpayers to pay as taxes to the state. The MMT integrates these two theories (credit theory of money and state theory of money) thus: the money that the state issues is state's debt from out of nothing and the state transfers the obligation to redeem state's debt to the tax-payers and when the tax-payers pay the tax, both the government and the tax-payer become debt-free (their debts are redeemed). Functional finance theory, put forward by Lerner (according to MMT) comprises of two basic ideas: one is, state can spend as much money as it needs to accomplish its duties and meet obligations without depending on receipts from tax and bond-sales; the second is the state will tax people to redeem the government's debt, to make the people accept its money (tax drives money), and to stabilize the value of money and will sale bonds to help people who want to save money in the bonds and to maintain the interest rate target of the central bank. According to Consolidation theory (developed by MMT), the government and the central bank (the Treasury of the Central Bank) cooperate with one another in executing monetary and fiscal policies to achieve the respective aims of those policies. MMT also thinks that there is a hierarchy of money from state money to private money in descending order; state money being in the highest ladder and private money being in the lowest order. The MMT concludes that the state can crate money and spend for its unlimited purchasing without being constrained by its limited incomes from tax-receipts and bond-sales till it achieve full employment and price stability.

Then, I will explain that the MMT does not really want to explore what money is or/ and the history of how money had been evolved as a medium of exchange. On the contrary, the MMT at first defined what money should be and then narrated the evolution of money in that light. MMT argues that in the modern capitalist system money in nothing but a numeraire or money of account or credit (debt) money having no intrinsic value of its own and that money is not pegged to commodity or a medium of exchange. They define the instrument of exchange not as money but as monetary instrument (credit money) and a sale or a purchase is nothing but an exchange of a commodity for a credit. Having thus defined money, the MMT begins to impose this theory on the history of money's evolution. Therefore, their theory of money does not reflect the fact how money evolved and is imaginary one.

Thereafter, I will try to explain what should be real definition of money and how monetary and fiscal systems are working. 
In the conclusion, I will make a summary of what the MMT is and will make some suggestions. In the end, I will explain why and how my findings are new additions to the existing knowledge on money, monetary policy and fiscal policy.

\section{Literature Survey:}

Here, I will briefly narrate what the MMT is about. I found that the theories of MMT are founded on grossly wrong theories formulated by earlier economists. They are: the Credit (debt) Theory of Money, the State Theory of Money, theory of Hierarchy of Money, theory relating to Taxes and Bonds, theory of Functional Finance, theory of Consolidation between the Central Bank and the Government, theory of Government is the Employer of Last Resort

\subsection{The Credit (Debt) Theory of Money:}

The MMT is heavily indebted, for this theory, to the book "The Credit Theory of Money" of A. Mitchell Innes. Innes explained his 'credit theory' thus: "Shortly. The Credit Theory is this: that a sale and purchase is the exchange of a commodity for credit. From this main theory springs the sub-theory" that "the right of the debtor to release himself from his debt by the tender of an equivalent debt owed by the creditor, and the obligation of the creditor to accept this tender in satisfaction of his credit." [Innes 1914, p.152]

However, this theory is full of flaws and unintelligible contradictions. The very basic foundation of Innes' credit theory "that a sale and purchase is the exchange of a commodity for credit" is erroneous and does not corroborate to the facts. A sale or purchase can only be complete if the values of the things (commodities or services) that are being exchanged become equal. After the purchase or sale, neither party (seller or purchaser) (both are seller or purchaser in their turn) remains creditor or debtor to one another. A sale or purchase will be the exchange of a commodity for credit if, and only if, the purchaser cannot offer anything of same intrinsic value against the thing (having an intrinsic value) that he buys and gives his IOU of the same value to the seller. Therefore, it is not 'a sale or exchange' that Innes wants us to accept, but borrowing or lending that Innes refers as "a sale and purchase". 'the exchange of commodity for credit' takes place in a borrowing and lending, not in 'a sale and purchase'. Therefore the basic concept (Innes considers it as his "main theory") "'that a sale and purchase is the exchange of a commodity for credit" is a wrong or hypothetical on which Innes' 'the credit theory of money' is based/ founded.

Innes continues, "From this main theory springs the sub-theory that the value of credit or money does not depend on the value of any metal or metals, but on the right which the creditor acquires to "payment," that is to say, to satisfaction for the credit, and on the obligation of the debtor to "pay" his debt and conversely on the right of the debtor to release himself from his debt by the tender of an equivalent debt owed by the creditor, and the obligation of the creditor to accept this tender in satisfaction of his credit." Innes describes how this system functions thus: "A is debtor to $B$ and gives his obligation or acknowledgement of debt. Shortly afterwards, $B$ becomes debtor to $A$ and hands back the acknowledgement. The debt of $A$ to $B$ and of $B$ to $A$, the credit of $B$ on $A$ and that of A on B are thereby cancelled." [Innes 1914, p. 161].

However, this is the most impracticable theory. Here, Innes argues that the buyer (debtor) can or must redeem his debt by not offering anything of intrinsic value as repayment (redemption) of his debt to the seller (creditor), but "by the tender of an equivalent debt owed by the creditor". However, it is possible to get "an equivalent debt owed by the creditor" only if the creditor (seller) 
buys something of equivalent value from the buyer at a later time. In that case, once someone buys something from someone, the process must be reversed, that is the seller must buy something of 'equivalent value' from the buyer at a later debt. This process can only be completed if the buyer possess something of 'equivalent value' what the seller wants to buy later. Then, it means that "a sale or purchase" must be reversed to get "the debtor [buyer] to release himself from his debt [to the seller]". However, if every time "a sale and purchase" is to be reversed, then selling and purchasing will be very cumbersome and almost impossible. The process of lending first and being repaid back later cannot help trading in marketplace where people buy and sell things and people have no option to reverse their dealings either with the buyers or the sellers later.

Innes knew this problem very well. However, Innes' intension was not to stick to his own theory. First, he formulated a theory, then twisted his own theory. He wants to establish another theory that though the "fundamental theory" is that "the debtor to release himself from his debt by the tender of an equivalent debt owed by the creditor", but "in practice it is not necessary for a debtor to acquire credits on the same persons to whom he is debtor". [Innes 1914, p. 152]. What Innes wanted is to suggest is not that the buyer (debtor) should 'acquire credits on the same persons to whom he is debtor, but acquire credit on the other persons to redeem his debt to his creditor (seller). But, again, Innes knew full well that it is almost impossible to obtain an "equivalent debt" from a third party buyer (debtor) and that the seller may not accept a debt of a third party from his debtor. It was not the intension of Innes also to assert. His hidden agenda was to establish that a debtor must acquire a debt only of a bank (and form none other than a bank) and must pay his debt to the seller paying the banks debt (and debts of none but the bank). Thus, Innes shifted from or twisted twice his 'fundamental theory' that "a sale and purchase is the exchange of a commodity for a credit". First, he altered his 'fundamental theory' by asserting that the buyer (debtor) must acquire a debt of a third party, and then (for second time), he altered this argument by suggesting that the third party must be none other than a bank (just debt of any third party will not do). Therefore, Innes writes, "Such is the fundamental theory, but in practice it is not necessary for a debtor to acquire credits on the same persons to whom he is debtor. We are all both buyers and sellers, so that we are all at the same time both debtors and creditors of each other, and by the wonderfully efficient machinery of the banks to which we sell our credits, and which thus become the clearing houses of commerce, the debts and credits of the whole community are centralized and set of against each other. In practice, therefore, any good credit will pay any debt." [Innes 1914. p. 152] Here Innes argues that when we buy goods and services we pay with the debt of the bank (according to Innes a third party), the debt that banks owe to us, when we deposit our credits in the bank. However, though Innes writes," We are all both buyers and sellers, so that we are all at the same time both debtors and creditors of each other", he does not really meant to hold both parties in "a sale or a purchase in the exchange" as both as creditor or/and seller in their turn; Innes' purpose was to establish that only the buyer (who pays money in exchange of something when buying) is a debtor (not creditor) and only the seller of a thing (not money) is a creditor (not debtor). Therefore, here, also Innes twisted his argument that the both the seller and the buyer are either debtor or creditor by reasserting that only buyers will be treated as debtor and only the seller will be treated as creditor. 
Innes revised his earlier argument that debt instrument of any third party will do by the new argument that this third party must be a bank only whose debt-instrument a debtor (buyer) must acquire to repay his debt to the creditor (seller). Innes refers to a "wonderfully efficient machinery of the banks to which we sell our credits" and we buy something with the debt (that the banks owe against our credit in the banks) of the bank. Innes writes, "Again in theory we create a debt every time we buy and acquire a credit every time we sell, but in practice this theory is also modified, at least in advanced commercial communities. When we are successful in business, we accumulate credits on a banker and we can then buy without creating new debts, by merely transferring to our sellers a part of our accumulated credits. Or again, if we have no accumulated credits at the moment we wish to make a purchase, we can, instead of becoming the debtors of the person from whom we buy, arrange with our banker to "borrow" a credit on his books, and can transfer this borrowed credit to our seller, on undertaking to hand over to the banker the same amount of credit (and something over) which we acquire when we, in our turn, become sellers." [Innes 1914, p. 152].

However, it is not also the purpose to establish that the debt (issued against our credit deposited in the bank) is the only third party's debt that we pay when we buy. Innes' intention is establish the debt of the government (and not of the banks) as the only debt instrument that must be considered as third party's debt that we can pay when we buy. Therefore, after mentioning "the wonderfully efficient mechanism of the banks" as the only provider of debt (that Innes considers to be the debt of third party to be paid to the seller), Innes hastened to refer to government as the only source/ provider of 'third party's debt' that we can pay when we buy. Innes writes, "Then again, the government, the greatest buyer of commodities and services in the land, issues in payment of its purchases -- vast quantities of small tokens which are called coins or notes, ... and these credits on the government we can use in the payment of small purchases in preference to giving credits on ourselves or transferring those on our bankers. So numerous have these government tokens become in the last few centuries and so universal their use everyday life - far exceeding that of any other species of money - that we have come to associate them more especially with the word "money."'. [Innes 1914, p. 152].

Thus, Innes, initially started by saying that, in a sale or purchase, a buyer (debtor) must pay the seller (creditor) the seller's debt. Then Innes added the debtor may find any third party's debt (instead of a debt of the seller) to pay for redeeming his debt to his creditor (seller). Again, Innes shifted his position. He asserts that debt of any third party will not do; only the debt of a bank must be treated as the third party's debt that we must produce to buy things. Again, Innes shifted his position by saying that only the debt of the government (that the government incur in purchasing our goods and services) must be treated as the third party's debt that we must pay when we buy anything.

One thing remains unintelligible. If we must acquire a debt (as third party's debt) instrument from a bank or a government in exchange of/ against a deposit of our credits (commodities) to be able to pay for what we buy, when we cannot pay those commodities (commodity-money) directly to the seller when we buys something. Innes argues that before we can use a commodity as money the commodity has to be stamped or minted by some authorized minter. Banks and the governments are the accepted minters who stamp or mint the commodity into commodity-money. Innes argue that when a person deposits a lump of commodity (gold or silver) in the mint of a 
bank or government and the mint hands over the depositor a stamped commodity-money, it is not just handing back to the owner (depositor) of the commodity in the form of money; but an act of buying and selling. Innes argues according to the law of "a sale and purchase is the exchange of a commodity for a credit", the mint just becomes a debtor when it buys (receives) the lump of a commodity (gold or silver) and repays its debt to its creditor (the seller/ owner of the commodity) with a stamped-money (commodity money) that, according to Innes, is the debt-instrument of the bank. Thus, according to Innes, each stamped and minted money is a debt-instrument of the minter/ minter (bank or government). Innes writes, "The Government of the United States does not profess to buy gold. All it professes to do is to accept it on deposit, make it into bits called standard dollars, stamp them with a guarantee of weight and purity, and hand them back to the owner, or, if he wishes it, he will be given a certificate or certificates in place of the gold. Now I again wish to emphasize the fact that it is not what the government professes to do that matters, but what it actually does. The fact that the law regards this transaction as a deposit does not make it so. The transaction is not really a deposit, but a sale and purchase. In exchange for each ounce of gold the owner receives in money. If the gold were merely taken on deposit, or for the purpose of stamping it without, giving, to the owner of the stamped metal, any special right to pay his taxes with his gold, that is to say without investing the gold with the character of an obligation, without making it into money, the transaction would be a deposit, but not otherwise." [Italics are mine] [Innes 1914, p. 162].

Here, Innes argues that stamping on the coin is a kind of "investing the gold with the character of an obligation" for the holder of money (coin) "to pay his taxes with his gold". It means that by only stamping on the coin, the government obliges the holder of the coin (who comes to mint his bullion into coin) to pay tax to the government to redeem government's debt. However, these coins are not those coins that the government spends to purchase commodities and services. The coins that the government spends are minted by the government mint out of the gold and silver that the government has already reserved in its treasury. If the coins that are minted and handed over to the people who come to mint their gold and silver into coins are regarded as debt of the government and if the government obliges the holder of that coins to repay its (government's) debt by way of tax payments, then, how can those coins, that are minted out of the government's bullion reserve, also become debt of the government that also must be redeemed by the same way of payment of taxes by the receiver (the seller who sells his services or commodities to the government)? Both types of coins minted by the government mint (one that is minted for the people who brings gold for minting and another that is minted out of government's own bullion cannot be treated as debt of the government. The fact is that none of these two types are government's debt as Innes wants us to accept or believe.

However, it is unintelligible if "In exchange for each ounce of gold the owner receives in money', how that act of exchange acquire the quality of "investing the gold with the character of an obligation" of the government. What Innes willfully avoids in stating that the minter (bank or government) does not just exchange money with an ounce of gold, but receives a wage/ minting charge. If I hire a carpenter to make a table and pay him his wage, will it be considered that I receive the table as a debt-instrument of the carpenter and that the table is not my own? Besides, if I pay gold in purchasing steel, why the payment of gold will be treated as a debt-instrument, while both the commodities that are exchanged are metal? If I exchange banana with fish, which of these two commodities will be considered as debt-instrument? We will not be able to answer these questions correctly if we adhere to the theory of Innes. Against all these odds, Innes still 
argues that government money "have no more claim to the title than any other tokens or acknowledgement of debt" [Innes 1914, p. 152] and asserts that "The government-stamp on a piece of gold changes the character of the gold from that of a mere commodity to that of a token of indebtedness." [Innes 1914, p. 168]. Therefore, Innes is wrong in trying to establish his "fundamental theory" of "a sale and purchase is the exchange of a commodity for credit."

Innes argues that a debtor (buyer) must redeem his obligation of debt by offering an equivalent debt of the creditor (seller). Innes writes, "the debtor to release himself from his debt by the tender of an equivalent debt owed by the creditor" [Innes 1914, p. 152]. Innes gives an example how a debt of a buyer (debtor) can be redeemed by paying the debt of the creditor (seller) to the creditor. He writes, "government's debt (the money that the government pays for purchasing) to the seller (creditor, here the people from whom the government buys) can be redeemed by paying tax to the government with the government's money (government's debt). But it is a wrong argument and contrary to Innes theory that debtor must redeem his debt by paying creditor's debt to creditor; in this case, creditor (the sellers, the people) are paying debtor's debt to the debtor (the government) as tax to redeem the debtor's (government's) debt. It seems that Innes wants to prove that the money is government's debt, by hook or by crook, even if his "fundamental theory" has to be contradicted. In arguing this way, Innes misleads us that tax is a debt. Tax is not a debt; it is a payment against government services that the people receive in exchange of paying tax.

Innes also misleads us by stating that money is a debt when the money (coin and certificate of commodity) is a commodity. If any other commodities like iron, banana, fish, and teaching are not debt, then money (gold and silver) also is commodity and not debt. However, Innes argue that "The value of credit does not depend on the existence; of gold behind it, but on the solvency of the debtor." [Innes 1914, p. 168]. Then why did Innes is bent on asserting that even commoditymoney is a debt? Innes' answer is that the value of a unit of commodity money differs from place to place and from time to time, content of metal differs among the monies known as dollar in different areas, people usually reduce the shape and size of a coin through continuous clipping; thus dollars can vary in their weight, value, size and acceptability. Innes writes, "As can be clearly proved by careful study of history, a dollar or a pound or any other monetary unit is not a fixed thing of known size and weight, and of ascertained value, nor did government money always hold the pre-eminent position which it to-day enjoys in most countries - not by any means." [Innes 1914, p.152] Innes cites examples: "the German States, where there were literally hundreds of monetary standards, all called the same name of Mark -- the history of money is particularly involved, and the fact that the retail trade always followed a lower standard than did the wholesale trade in the same place." [Innes 1914, p. 154]. "It is hard to get the public to realize this functional principle, without a true understanding of which it is impossible to grasp any of the phenomena of money. Hard, too, is it to realize that in America to-day, there are in any given place many different dollars in use" [Innes 1914, p. 154]. "Everybody who incurs a debt issues his own dollar, which may or may not be identical with the dollar of anyone else's money. It is a little difficult to realize this curious fact" [Innes 1914, p. 154]

Therefore, according to Innes, if dollars are not uniform and cannot be identified by its weight, value, size and acceptability (because they differ in different areas and times) then the dollar does not derive its acceptability and/ or value from its metal content. So, Innes prefers to think dollar as a nomenclature of a debt that the issuer of dollar is obliged to pay/ offer. Innes argues in this effect that, "What is stamped on the face of a coin or printed on the face of a note matters not at 
all; what does matter, and this is the only thing that matters is: What is the obligation which the issuer of that coin or note really undertakes, and is he able to fulfill that promise, whatever it may be?" [Innes 1914, p. 155] Even the government dollars were not uniform all the time and their value and acceptability differed from time to time. Innes writes, "A government dollar is a promise to "pay," a promise to "satisfy," a promise to "redeem," just as all other money is. All forms of money are identical in their nature." [Innes 1914, p. 154] Therefore, Innes concludes that, "Credit and debt are abstract ideas, and we could not, if we would, measure them by the standard of any tangible thing. We divide, as it were, infinite credit and debt into arbitrary parts called a dollar or a pound, and long habit makes us think of these measures as something fixed and accurate; whereas, as a matter of fact, they are peculiarly liable to fluctuation." [Innes 1914, p. 155]

However, Innes is wrong in understanding that coins and certificates do not derive their value from their commodity content but are valued as on debt (obligation of a debtor), because even if it is a debt it must have some face value at par which the debt will be accepted and used as payment to the satisfaction of the seller (creditor). Where from the debt derives its face value? Innes answers that, "The value of credit (according to Innes, issuer's debt in the form of money) does not depend on the existence; of gold behind it, but on the solvency of the debtor (issuer of money)" [Innes 1914, p. 168]. He further explains, "The holder of a coin or certificate has the absolute right to pay any debt due to the government by tendering that coin or certificate, and it is this right and nothing else which gives them their value." [Innes 1914, p. 161]. Innes adds, "a government issue of money must be met by a corresponding tax. It is the tax which imparts to the obligation its "value." A dollar of money is a dollar, not because of the material of which is made, but because of the dollar of tax which is imposed to redeem it." [Innes 1914, p. 165]. However, these answers of Innes does not satisfactorily meet the question where from the debt (money) derives its face value. Just returning or redeeming the debt to its issuer does not answer what the face value of the debt in units should be. Every debt (money) is not of the same face value; why different debts (monies) bear different face value? Innes' answers are ambiguous. The answer is that every debt (money) bears the face value equal to the value of the units of metal (commodity) that it contains. Its value may change according to the market phenomena of supply and demand; if its metal content is reduced through continuous clipping, the value of the money also reduced to the same extent. During Innes' time money was either commodity money or a paper-note issued against the reserve of commodity of equal value. Therefore, whether money (debt) is redeemable or not, or whether tax must be paid in money (government's own debt) or not, money derives its value only from the commodity of which it is made or from the commodity-reserve against it is issued and not because "Government money is redeemed by taxation" [Innes 1914, p. 168] and "It is the tax which imparts to the obligation its "value"" [Innes 1914, p. 165] as Innes wants us to believe. Innes explained that "coin or certificate ... acquired their value by taxation." [Innes 1914, P. 160]. Innes writes that "The issue of money is not an exclusive privilege of government, but merely one of its functions, as a great buyer of services and commodities. Money in one form or another is, in fact, issued by banks, merchants, etc." [Innes 1914, p. 168]. If government's debt (money) must be redeemed by taxation, then by the same logic, bank's debts (money) must also be redeemed by taxation to the bank. However, Innes does not argue in that way; on the contrary he writes, "A banker is one who centralizes the debts of mankind and cancels them against one another. Banks are the clearing houses of commerce." [Innes 1914, p. 168]. Then redemption of money does not necessitate payment (of tax) of money (debt) to its issuer (government). 
Thus, redefining money as debt of its issuer does not in any way help to understand clearly what money is or what is the functions of money; or in no way improves the monetary or economic situation. On the contrary, defining money as debt blurs our vision in understanding what money is. Innes argues that when a person deposits an ounce gold in a bank and gets a coin against it; the money must be considered as debt of the bank. We know that when a person deposits any money in a bank and the bank issues it's IOU (savings accounts pass book) then the IOU is a debt of the bank. Now, the question is whether both of these (money and IOU) should be treated as debt of the bank. If we accept Innes' theory that money is debt of the bank then we must treat the IOU as money of the bank but that is clearly not so.

Innes writes, "It is true that all the government paper money is convertible into gold coin; but redemption, of paper issues in gold coin is not redemption, at all, but merely the exchange of one form of obligation, for another of an identical nature." [Innes 1914, p. 165]. However, Innes is wrong. The paper money is issued against the gold coin. Therefore, the value of gold coin is equal to the face value of the paper money. Therefore, by converting a paper money into gold cannot be "one form of obligation", because the gold coin represents the full value of the paper money and not an IOU of the government.

Innes writes, "The object of commerce is the acquisition of credits." [Innes 1914, p. 168]. Innes is right if he means wealth by the term credit; but is wrong if he means debts of third person by the term credit. Because, nobody wants just to sell forever and accumulate another's debt (IOUs) without getting any wealth; [purpose of selling something is to get another kind of wealth for consumption instantly or at a future date.].

The ultimate goal of Innes is to control inflation. He thinks that money is being created and supplied in excessive amount which leads to inflation. Innes writes, "Large reserves of "lawful money" in the banks are evidence of an inflation of the government currency. The inflation of government money induces a still greater inflation of credit throughout the country, and a consequent general depreciation of money. The depreciation of money is the cause of rising prices." [Innes 1914, p. 168]. Therefore, to control inflation, Innes thinks that some money should be regularly drained out circulation. Innes thinks that draining of money can only be done if some people are made to pay tax to the government. Innes expresses his concern thus: "The issue of coins in exchange for gold at a fixed and excessive price, without providing taxes for their redemption, causes an inflation of government money, and thus causes an excessive floating debt and a depreciation of government money." [Innes 1914, p. 168]. This goal could be achieved if a theory can be framed that tax is debt-obligation payable to the government by the people of a country. Innes did that by suggesting that tax is a debt that must be redeemed by payment of tax to the state. Therefore, Innes asserts that payment of tax is not a burden but a blessing. He writes, "We are accustomed to consider the issue of money as a precious blessing, and taxation as a burden which is apt to become well nigh intolerable. But this is the reverse of the truth. It is the issue of money which is the burden and the taxation which is the blessing." [Innes 1914, p. 160].

However, Innes is wrong in asserting that, "The issue of coins in exchange for gold at a fixed and excessive price, without providing taxes for their redemption, causes an inflation of government money, and thus causes an excessive floating debt and a depreciation of government money." [Innes 1914, p. 168]. If government buys goods and services paying the real price (value) that is the value of money that the government pays equals to the value of commodities that the government buys, then inflation cannot occur. Besides, taxation is not the proper way to reduce 
inflationary effect, because taxation reduces one's capability of buying by reducing his money what he deserves as his earning. Therefore, in the name of reducing inflation, taxation is really depriving one from what he deserves as his own. Therefore, taxation is a wrong way to reduce inflation.

Then why Innes feels it necessary to redefine money as debt. Innes himself could not grasp that. He writes, "But even when we have grasped this truth ("the basic theory that a sale and purchase is the exchange of a commodity for a credit and not 'for a piece of metal or any other tangible property. In that theory, lies the essence of the whole science of money."), there remain obscurities which in the present state of our knowledge cannot be entirely eliminated. What is a monetary unit? What is a dollar? We do not know. All we do know for certain-and I wish to reiterate and emphasize the fact that on this point the evidence which in these articles I have only been able briefly to indicate, is clear and conclusive-all, 1 say, that we, do know is that the dollar is a measure of the value of all commodities, but is not itself a commodity, nor can it be embodied in any commodity. It is intangible, immaterial, abstract. It is a measure in terms of credit and debt." [Innes 1914, p. 159].

\subsection{State theory of money}

State theory of money can be best understood if we first know the mainstream/ traditional/ orthodox / Metallist view about how money originated, what is money and what are the functions of money. According to orthodox view, money originated as a medium of exchange. Exchange "was initially conducted on the basis of barter, with individuals trucking their goods to the local trading venue and attempting to exchange what they brought for what they wanted. Thus, barter exchange required the famous 'double coincidence of wants' so that two-party exchange could only occur if each of two individuals wished to exchange that which they possessed for that which was offered by another. Money is said to arise spontaneously in the private sector in order to eliminate some of the inefficiencies of barter. Thus, society agrees upon some means of exchange called 'money' in order to overcome some of the transaction costs associated with barter." [Bell, April 1998, p.1] Regarding what is money, The Mainstream/ "The Metallists maintained that society settled on a metallic currency (gold, silver, etc.) so that the money would have (intrinsic) value. They believed that money's ability to fulfill the medium of exchange function depended "on its being a commodity with an exchange value independent of its form as currency" (Ingham 1996, p. 512). This, it was argued, was necessary in order for 'real' analysis to proceed; that is, there had to be an independent exchange ratio for every commodity (including money) with every other commodity. As a producible commodity, money was really no different from any other commodity; it merely represented the exchange of any producible commodity for any other producible commodity (Davidson, 1997). Thus, the Metallist theory suggests that problems in coordinating trade within a barter economy naturally led society to settle on precious metals as a medium of exchange." [Bell, April 1998, p.1-2] Bell writes, "Aristotle clearly supported the Metallist theory put forth so far, claiming that: "for the purpose of barter men made a mutual compact to give and accept some substance of such a sort as being in itself a useful commodity ... finally . . . impressing on it a stamp in order that this might relieve them of having to measure it; for the stamp was put on as the token of the amount" (quoted in Goodhart, 1996, Appendix B)" [Bell, April 1998, p. 2]. Regarding the function of money, mainstream economists view is that "Money is a matter of functions four, a Medium, a Measure, a Standard, a Store." [William Jevons (1875) 
famously defined money as having four functions and his ideas inspired Alfred Milnes to write this couplet in his book 'The Economic Foundations of Reconstruction'.]

However, the later mainstream economists like Samuelson mentions as money not only the commodities but other non-commodities also. He wrote, "Inconvenient as barter obviously is, it represents a great step forward from a state of self-sufficiency in which every man had to be a jack-of-all-trades and master of none ... If we were to construct history along hypothetical, logical lines, we should naturally follow the age of barer by the age of commodity money. Historically, a great variety of commodities has served at one time or another as a medium of exchange: ... tobacco, leather and hides, fur, olive oil, beer or spirits, slaves or wives ... huge rocks and landmarks, and cigarette butts. The age of commodity money gives way to the age of paper money. ... Finally, along with the age of paper money, there is the age of bank money, or bank checking deposits." [Samuelson 1973, pp.274-276] Here, Samuelson mentions commodity money (like gold and silver), token money (backed by commodity like gold and silver) and fiat money (paper-money) as money. This led to the problem of identifying what money really is; is it commodity with intrinsic value of its own or fiat money having no intrinsic value. Bell writes, "The Metallist vision easily adapted to the use of non-'pure' commodity or paper money. It was argued, for example, that non-'pure' metal coins could be substituted for commodity money because their metal backing would imbue them with value. Similarly, bank- or State-issued paper currency, under a metal standard, would be accepted because of its gold or silver backing. Thus, the Metallists retained the basic logical structure of their analysis by maintaining a link between these (fiduciary) currencies and precious metals (Ingham, 1996). When, from time to time, governments suspended convertibility, and paper continued to substitute for commodity money, the Metallists maintained that the currency retained its value because people expected convertibility to be restored." [Bell, April 1998, p. 2]. While, according to Metallists, "people were supposed to hold commodity money as "a medium of exchange that also [had] use as a consumption good or a productive input, at least potentially"' [Bell, April 1998, p. 2] it is not convincing why people began to accept "'fiat money is "a medium of exchange that will never be used as a consumption good or a productive input" (Kiyotaki and Wright, 1987, p. 5)." [Bell, April 1998, p.2] Why "the community did continue to accept intrinsically worthless paper currency after the elimination of a metal standard left a problem for Metallists/Monetarists to explain." [Bell, April 1998, p. 2]. "Perhaps the most famous 'solution' came from Walras who suggested that money could be reduced to a pure number, the numeraire. Money was to be viewed as nothing more than a representation or a symbol of 'real' goods; its development was irrelevant. As a numeraire, money was brought into the analysis only to allow the 'auctioneer' to announce prices (money numbers) in order to bring about market-clearing equilibrium." [Bell, April 1998, p. 3].

Besides, "It is not always clear whether the precious metals used in exchange were in an 'unworked' state or whether they had been minted/coined; however, Goodhart notes that exchange using unworked precious metals is more like barter exchange than monetary exchange and that payments in this form have been extremely rare because it would be difficult to 'identify' the quantity and quality of the metal (1996). This 'identifiability' problem usually meant that commodity money required a stamp or guarantee before it could circulate widely. Aristotle clearly supported the Metallist theory put forth so far, claiming that: "for the purpose of barter men made a mutual compact to give and accept some substance of such a sort as being in itself a useful commodity . . . finally . . . impressing on it a stamp in order that this might relieve them of having to measure it; for the stamp was put on as the token of the amount" (quoted in Goodhart, 1996, 
Appendix B) But it is not always clear who performed this minting function - private individuals/institutions or the government/public sector. Goodhart points out that the minting function has most frequently been performed by government (1996)." [Bell, April 1998, p. 2]. "For them [the Metallists], the State's role would have been limited to an "ex-post codification of social customs" (Laidler, 1987, p. 21). Thus, governments could encourage the continued use of metals by vouching for the integrity of the precious metals (the quality and quantity of metal), but their power would have been limited to supporting the will of the private sector. With the 'identifiability' problem resolved, metallic coins were accepted as a medium of exchange because their precious metal content gave them value independent of their form as currency. In other words, metallic coins were accepted because they were themselves valuable commodities with certain properties which made them a convenient medium of exchange." [Bell, April 1998, p. 2].

From the above two ambiguities of the mainstream economists regarding whether money is commodity of self-content value or just a numeraire and whether money is stamped by "private individuals/ institutions or the government / public sector" for its 'identifiability', the MMT chose money as a numeraire (not as commodity) or as 'fiat' money and chose government as authority for stamping money (not private individuals/ institutions as authority for stamping money) for 'identifiablity' of money. Thus, basic frame of MMT was created; that government creates money as a numeraire (not as commodity) having no intrinsic value of its own.

However, some questions still remain and that have to be answered. One question is if money is a numeraire (not a commodity), then from where does it get its value or why it is accepted. The MMT answers this question by inventing that money gets its value from the state's (government's) declaration that it will accept money in its pay-offices and the value of the units written on the money is determined also by the proclamation of the state that the units will be valued in terms of so and so units of commodities. "the Metallists were unable to convincingly cope with. The paradox - why should paper with no value continue to circulate? Recall that the early Metallists traced money's value to its precious metal content/backing but that modern money (inconvertible State or bank money) provides no such basis for value. The solution to the paradox, as Smith recognized, is that the paper is not without value!" [Bell, April 1998, p.3] Adam Smith explained, "'A prince, who should enact that a certain proportion of his taxes should be paid in a paper money of a certain kind, might thereby give a certain value to this paper money" ([1776] 1904, p. 312)".. [Bell, April 1998, p. 3]. Stephanie Bell, one of the most veteran MMT economist explains how Adam Smith's view matches the views of the MMT thus:" Smith's theory, unlike the Metallists', can be applied equally convincingly whether the medium in which taxes are due is fiat money, paper backed by a precious metal, or commodity money. Whatever the prince announces he will accept in payment of taxes will immediately imbue this medium with value for it will be demanded as a means of discharging the tax liability. Thus, irrespective of any inherent property or function they may come to serve, the value of these monies depends on their usefulness in settling tax or other liabilities to the State." [Bell, April 1998, p.3] ", the 'Anti-Metallists' or Chartalists see the creation of money as contingent upon the State's proclamation that a certain currency will be accepted by the State at face value. Thus, State money is created when the public agrees to hold (as an asset) state-issued currency (a liability to the State) which is required in payment of taxes. The Chartalist vision supported by Minsky is, therefore, consistent with his treatment of money as a two-sided balance sheet operation." [Bell, April 1998, p. 6]. 
Friedrich Knapp (from whom the MMT got the idea) states in his book "The State Theory of Money" that, ""[T]he money of a State is . . what is accepted at public pay offices" and "the standard is not chosen for any properties of the metals" [Knapp, 1924, p. viii]. And the values of the money will be determined by the 'conversion rate' proclaimed by the state. Kelton writes, "When, for example, the State announced that it would accept coined gold in payment of taxes, it also had to announce a nominal conversion price for gold. That is, the State had to tell its constituents how much of their nominal tax liability could be eliminated with gold. The State could announce that one ounce of coined gold will eliminate $\$ 35$ of one's tax liability. The coin, whether stamped 'one ounce' or ' $\$ 35$ ', will reduce one's nominal tax liability by $\$ 35$, regardless of its weight, at the time it is presented at State pay offices. Thus, it is the conversion rate, determined by proclamation, not its precious metal weight that determines its validity as a means of payment at State pay offices." [Bell, April 1998, p.5] Thus, MMT tried to establish that whether money contains any metal is irrelevant for how much value should the money carry. They suggest that "the State can make anything it chooses (metal coins, paper backed by some metal, or inconvertible paper) generally acceptable by proclaiming that it will be accepted at State pay offices. What makes a currency valid as money is a proclamation by the State that it will be accepted at its pay offices" [Bell, April 1998, p. 4]. Kelton also writes, "Smith, Knapp, Keynes and Minsky recognized the State's power to demand certain payments from its constituents (taxes, fines, etc.) as well as the power to determine both the unit in which these liabilities are denominated and the means by which they may be discharged. They also understood that the value of certain money derives from its acceptance at State pay-offices, not from any inherent value within/backing the currency itself. That is, support for the Chartalist vision of money as a 'creature of the State' can be found in each." [Bell, April 1998, p. 5]. Therefore, state's money gets it value from the need that tax must be paid in state's money. Minsky writes, "the fact that taxes need to be paid gives value to the money of the economy." [Minsky 1986, P. 231]. Thus, a state theory of money (MMT subscribe to this theory) is formulated. Thus, "Chartalist (state) theory does not view money as a commodity with exchange value, scarcely different from any other commodity. ... On the contrary, Chartalist (state) theory seeks to uncover the essential properties of money as a unit-of-account and a means of payment." [Bell, April 1998, p.3].

Wray, one of the chief protagonists of the MMT, explains the 'state money' thus: "For the past four thousand years ("at least", as John Maynard Keynes put it), our monetary system has been a "state money system". To simplify, that is one in which the state chooses the money of account, imposes obligations denominated in that money unit, and issues a currency accepted in payment of those obligations. While a variety of types of obligations have been imposed (tribute, tithes, fines, and fees), today taxes are the most important monetary obligations payable to the state in its own currency." [Wray June 2014, p-2] Wray wrote, "Our system is a state money system. Our currency is government's liability, an IOU that is redeemable for tax obligations and other payments to the state. The phrase "debt-free money" is based on a misunderstanding. Remember, "Anyone can create money", the "problem is to get it accepted". They are all IOUs. They are either spent or lent into existence. Their issuers must accept them in payment. They are accepted by those who will make payments, directly or indirectly, to the issuers." [Wray June 2014, p-7] 
Wray also argues that the government-expenditure is different from the household-expenditure as household cannot print money but government can print money. Wray argues that like household-expenditure government-expenditure is not constrained by only its income and borrowing. Wray writes, "In the case of a household, spending depends on income plus access to credit. However, the government's spending is said to be financed by tax revenue, "borrowing" (bond sales), and the printing of money. That final source of finance [the printing of money] is of course not available to the household," [Wray Jan. 2018, P 3].

However, this argument of the MMT is arbitrary. The MMT, without trying to explain the ambiguities regarding whether money is commodity of self-content value or just a numeraire and whether money is stamped by "private individuals/ institutions or the government / public sector" for its 'identifiability', tries to mislead us by reducing the authority of creating money to the state and by suggesting that the money (metal coins, paper backed by some metal, or inconvertible paper) gets its value not from its metal (commodity) content but from state's declaration of what value an unit of money will carry. Thus, MMT wants us to accept that the coin-moneys that were created by the private banks (alongside the creation of coin moneys by the kings) were not accepted at par their metallic value but got their value from the proclamation of the banks. The fact is that no coined money got their value from any proclamation from their creators (either the states or the bankers). They were valued according to their metal content and not as the proclamation valued them as the MMTers want us to accept when they write "If, however, their validity is retained after their wearing down has been noticed, then their continued use is in accordance with proclamation and they are Chartal." [Bell, April 1998, p. 4] to make us believe that the even after the wearing down of the weight of a commodity-money, the commodity-money were circulated and accepted at par their face value and not at par their metal-content. The following quotation from Kelton does not match with their claim of money being valued at par their creators' proclamations. Kelton writes, "To understand why the State objected to the debasement of precious metal coins, we must understand the reason for taxation. The purpose of taxation is to get people to work and produce for the State. That is, the State wants bridges, armies, etc. and gets the private sector to produce them by imposing taxes. To pay the taxes, the private sector must acquire the State's money. By debasing coins, gold could be brought to the mint, coined, and exchanged against the unit of account in order to reduce one's tax liability. The community, then, would have been able to satisfy their nominal tax liabilities by producing less for the State." [Bell, April 1998, p. 4]. From this quotation it is clearly reveals that value of coins was measured at par their metal-content (and not at par the value proclaimed by the state as the MMT claims it to be). Otherwise, tax-payers could not use [debased] coined gold ('clipped' or 'shaved') "to reduce [their] tax liabilities." [Bell, April 1998, p. 4], and precisely that is "why the state objected to the debasement of precious metal coins." [Bell, April 1998, p. 4].

Therefore, coins did not derive its value from the proclamations of the kings but from their metal (commodity) value. If a full-bodied gold coin was clipped or shaved up to $50 \%$, the value of the coin would reduced also to $50 \%$ of its market value with regard to its exchangeability with other commodity or services. Therefore, it is wrong to accept "their (debased coins) validity retained after their wearing down has been noticed" and that "their continued use in accordance with proclamation" [Bell, April 1998, p. 4], as the MMT wants us to accept. The fact is that all coins either (issued by the Kings or by the individual bankers) were/ are accepted and valued at par their commodity (metal) content. 
Now, the question remains, why the fiat moneys were/ are accepted and how they were/ are valued. The answer is not what the MMTists suggest that fiat moneys get their value from proclamations of their creator (the King, according to MMT); but because they were/ are accepted as the user/ holder of the fiat moneys believed that the creator must have the reserve in their custody the commodity (gold or anything) that corresponded/ corresponds to their face value. It is the fraudulence on the part of the creators (kings or bankers) that they created/ creates money without keeping any reserve against the fiat moneys that they created/creates. That is no fault of the users/ holders. When it was revealed/ reveals that the creator of money (either the king or the bankers), the people refused/ refuses to use that fiat money.

The MMT mistakenly believes or wants us to believe that state creates fiat money. Nowadays, State only creates metal coins that is valued and accepted at par their metal content. If their commodity contains are less than their face-value, that is because the cost of making (collecting the metal, minting, and transportation) is added to the coins. The fiat money that comprises the maximum percentage of the aggregate money in circulation is not created by the state or government. The central bank is the only authority to issue money. It issues money generally against the government's bond as reserve. They treat the government bonds as valued reserve against the fiat money they issues. If the government bond is nothing but mere a scrap of paper, that is no fault of the users/ holders of money. The central bank lends (lending is the only way through which fiat money can enter into the economy for circulation) the fiat money as if it is backed by some reserve of intrinsic value. Because, they lend the money (as if commodity money) and charges interest on the fiat money along with repayment of the fiat money. However, it is irrelevant to the users/ holders whether the money is fiat or issued against any reserve of intrinsic value; because in both cases (commodity money or certificate of commodity money and fiat money) the borrower were/ are bound to pay the interest and repay the principal borrowed amount. Therefore, even if money is created out of nothing or against some scrap of papers (government bonds) the value of money remains the same (as commodity money) to the users/ holders. That money is issued against nothing or something having no intrinsic value is a fraudulence on the part of the central bank who creates money against nothing (or valueless thing) and passes that money to its borrowers as if it is lending the right of some commodity to the borrowers to use for the period of the term of the borrowing. What is the most important issue here is that mainstream economists did not clearly state that money-creation by the central bank out of nothing (or something valueless) is out and out a fraudulence activity on the part of the central bank. Therefore, though fiat money is being created out of government bonds (government's paper IOUs) having no intrinsic value, yet it is treated as a token money (certificate of some commodity) that is believed to be in the reserve of the central bank. Therefore, without accepting this fact (fraudulence of the central bank), the MMT tries to make us believe that money (both commodity money and fiat money) is only a numeraire and derives its value from the proclamation of the creator (the state and the banker) of money and not commodity. Therefore, even fiat money still holds its commodityness and is valued and accepted as if it represents some commodity that is believed/ supposed to be reserved in its creator's custody. It is the fraudulence that the creator of money (the central bank) does not keep any commodity against the money that it creates as token money (as certificate of commodity and not as fiat money). Therefore, MMT's argument that only state creates money and that money is just a numeraire and that money is not 
commodity and that money derives its value from the proclamation of its creator or issuer (the King or the government) are grossly wrong and have no basis except fantasy.

Wray argues that as currency (money) can be printed without reserve of any gold (or any commodity) after 'gold standard' is abandoned and, therefore, government can print as much it needs without being afraid of redeeming the currency into gold or other commodity. Quoting from Ruml, Wray writes, "Final freedom from the domestic money market exists for every sovereign national state where there exists an institution which functions in the manner of a modern central bank, and whose currency is not convertible into gold or into some other commodity." [Wray Jan. 2018, P 7].

However, the above argument of Wray (or of the MMTists) is a half-truth. State was not the only issuer of money; banks also issued money in the past. However, now-a-days, government does not create money; only the central bank creates money. Wray himself accepts that only central bank creates money when he writes, "The United States is a national state which has a central banking system, the Federal Reserve System, and whose currency, for domestic purposes, is not convertible into any commodity. It follows that our Federal Government has final freedom from the money market in meeting its financial requirements." [Wray Jan. 2018, P 7]. Besides, though gold standard has been abandoned, yet money is pegged to something and that something is government-bonds. Wray did not clearly state that, now-a-days, the central bank creates money against its reserve of government-bonds value of which is equal to the value of the money that the central bank creates. The government did not get freedom from converting money into gold or something precious metal; it is the central bank that has got freedom from converting money into gold. Government, by no way, is the beneficiary of the abandonment of gold standard. Government is still dependent (as it was earlier when money was on gold standard) on taxreceipts and bond-sales for its budgetary income and expenditure. Therefore, Wray is wrong when he differentiates household spending and says that one source of government finance is "the printing of money" that the household don't have. Wray writes, "In the case of a household, spending depends on income plus access to credit. However, the government's spending is said to be financed by tax revenue, "borrowing" (bond sales), and the printing of money. That final source of finance [the printing of money] is of course not available to the household," [Wray Jan. 2018, P 3].

However, state cannot print money to increase its spending according to its needs. Wray writes, "The state no longer spent its IOUs, but rather ran its fiscal operations through its central bank, issuing bills, receiving credits to its account, spending central bank IOUs and receiving the same in tax payments." [Wray March 2014, P.27].

Wray is wrong in saying that government expenditure is different from the household expenditure because household cannot create money like the state that can create money. Wray himself writes, "In the late 1960s the microeconomic household budget constraint was applied to government budgets (spending is "financed" by taxes, borrowing, or money printing). We've essentially been stuck with that view ever since. A sovereign's budget is "just like a household's," so it must adopt "sound finance."” [Wray March 2014, P.27].

From the above discussion, it is clearly proved that the MMT's assertion that money is a "creature of the state" and that money gets its unit-value and acceptance from the proclamation of its creator (the king, in the past and the government, at present) and that money is nothing but a numeraire 
(number) having no intrinsic value and that money is debt of its issuer (the state or government) is fallacious, unrealistic and a hoax.

Therefore, the clam of the MMT that, "in practice in all modern monetary systems, the state plays an active role in the monetary system. It chooses the unit of account; it imposes tax liabilities in that unit; and it issues the money thing that is used by private markets for ultimate clearing. Any story of money that leaves out an important role for the state represents little more than fantasy, a story of what might have been, that sheds little light on the operation of real world monetary systems" [Éric Tymoigne and L. Randall Wray July 2005, p. 19] is itself a fantasy and not the real world monetary system.

\subsection{Theory of Hierarchy of Money:}

The very phrase the "hierarchy of money" tells that there are many types of "money" and their statuses are unequal. This is because MMT distinguishes between a 'money of account' and 'money'. According to Keynes, "the money of account is the description or title and the money is the thing which answers to the description" (Keynes 1930, p. 3). "if the same thing always answered to the same description, the distinction would have no practical interest. But if the thing can change, whilst the description remains the same, then the distinction can be highly significant" (Keynes 1930, p. 3). As different things answer to the description of the 'money of account', therefore, there exists, what Minsky calls, a "hierarchy of monies" [Minsky 1986, p. 228]. The 'title' or 'description' to which all money in the hierarchy must answer is, according to Chartalist theory that money is a 'creature of the State', dollar that is the state's currency in the USA. Therefore, in the USA, all types of moneys that are accepted and circulated are dominated in dollar unit. According to MMT, "the unit in which State money is denominated and in which taxes are due determines the unit of account for all money in the hierarchy" (Keynes, 1930; Lerner, 1947; Wray, 1997)." [Bell April 1998, p. 6]. Bell explains how and why state money is regarded as the highest form of money in the hierarchy. She writes, "It is fairly easy to see how the State's liabilities/promises may come to serve as a means of payment and a medium of exchange in private transactions. As Lerner recognized, the modern state can, by accepting it at its pay-offices, "make anything it chooses generally acceptable as money" (Lerner 1947, p.313). He stressed that it is not their status as legal tender but their acceptance in payment of taxes that makes the State's promises the most acceptable/liquid money in the hierarchy. He maintained that it is not enough for the State to simply declare that something is money (i.e. to define it as legal tender) for "its general acceptability, which is its all-important attribute, stands or falls by its acceptability by the state" (Lerner, 1947, p. 313)." [Bell April 1998, p. 8].

However, all the 'thing's (money) that are denominated in dollar are not of equal status. "Recall that money represents a promise to pay/IOU and that these promises can be created by anyone. The "secret" to turning these promises into money is getting other individuals or institutions to accept them. Therefore, the 'hierarchy of money' can be thought of as a multi-tiered pyramid where the tiers represent promises with differing degrees of acceptability (Foley, 1987)." [Bell April 1998, p. 6]. In this hierarchical system, the money (IOU) of the lower order will be converted into money (IOU) belonging to any higher order of the hierarchy. Bell explains this system thus: "We can consider the group of potential promise-makers to be: the government, banks, firms (non-bank) and households. When a firm makes a promise (issues, say, commercial paper), it 
promises to convert this promise, on some specified date, into a bank's promise, a demand deposit. Likewise, when a household makes a promise (issues debt to, say, a credit card company), it promises to convert its promise into a bank's promise. In the above, the "secret" to getting household and business debts accepted is a proclamation that they are convertible - at least potentially - into the promise of someone higher in the pyramid. Commercial paper, bonds, and credit card debt will (assuming the issuer does not default) be retired by delivering the promise of a bank." [Bell April 1998, p. 7].

However, money (IOU) (state money or bank money), that is also the "money of account" into which all "money-thing" must finally be converted, need not be converted into any higher form of money (IOU) because there is no higher form of 'money of account' than the state money. Bell explains, "This condition [of convertibility into higher forms of money/ IOU] does not, however, apply to all money in the hierarchy. Unlike households and firms, State promises and certain bank promises would be accepted even if they were not convertible into anything else. Even though, today, banks make their promises (demand deposits) convertible, on demand, into the State's promises (government money), this is not the reason they are accepted. It is because bank money is accepted at State pay-offices that it, along with State-issued currency, is considered by Knapp to be the 'decisive' money of the system." [Bell April 1998, p.7] Quoting Foley, Bell argues, "As Foley noted, "the State does not have to pay its liabilities by transferring something else" (Foley 1987, p. 520). Thus, neither the State nor the banks rely on convertibility for acceptance of their promises; what makes them both acceptable is not convertibility into something else but acceptance in payment to one's creditors." [Bell April 1998, p. 7]. Bell also writes, "Although the State's liabilities reign supreme among promises, certain bank promises, as a consequence of their acceptance at State pay-offices, also come to serve as means of payment and media of exchange. In particular, "[d]emand deposits have attained a special status in our economy because of the special role commercial banks have come to play" (Wray, 1990, p. 291)." [Bell April 1998, p. 8]. These three quotations from Bell clearly prove that, according to MMT state money and bank money is in the highest order in the hierarchy of money and these two types of money need not be converted into any higher form(s) of money as there is no higher forms of money (IOU) issued by any higher authority.

The degree of acceptability of different kinds of money determines their rank/ order in the hierarchy of money. Because of their highest degree of acceptability the state money and the bank money are in the apex of the hierarchy. Bell writes, "Recall that a money's place within the hierarchy depends on the degree to which it is accepted by society. As the 'decisive' money of the system, both the State's promises and banks' promises rank high among the monies of the hierarchy." [Bell April 1998, p. 7]. Next in the hierarchy of money (second tier in the pyramid) comes the money issued by the commercial bank. Bell writes, "Because the central bank guarantees that demand deposits [created by commercial banks] will trade at par with government currency and because they are accepted in payment of taxes, bank promises (demand deposits) are nearly as liquid as State money and therefore occupy the second tier in the pyramid." [Bell April 1998, p. 8].

Degree of acceptability (rank in the hierarchy) of moneys depends on the degree of their liquidity. If money is more readily converted into money higher in hierarchy without loss of any value, then that money's liquidity (and also acceptability) is more than the money which is less liquid. According to MMT, "The promises of firms and households occupy the third and fourth tiers, 
respectively. This is because there is at least some chance that they will not trade at par with government money (which is needed to pay taxes). For example, a firm may sell bonds to finance the purchase of a new plant. Although the firm promises to pay a certain nominal amount to the holders of these bonds, their value may vary over time (for example, with default risk and/or as interest rates change). Thus, as assets to their holders, these bonds will be less liquid than bank money because they can not necessarily be "quickly converted into the medium of exchange with little loss of value" (Wray 1990, p.16; my emphasis). Still, firms' promises are more readily convertible into the medium of exchange (i.e. are more liquid) than households' promises because better secondary markets exist for their resale. To get business and household debts accepted, they might be made convertible into the debt of someone higher in the pyramid and may also require interest payments to compensate for the risk associated with holding less liquid assets." [Bell April 1998, p. 8].

Besides, the kinds of moneys described above, there are other types of moneys that are the least liquid and acceptable. Wray writes, "MMT talks about a "money pyramid", with the state's own currency at the top. Bank "money" (notes and deposits) are below the state's "money" (reserves and currency). We can think of other financial institution liabilities as below "bank money" in the pyramid, often payable in bank deposits. Lower still we find the liabilities of nonfinancial institutions. And at the bottom we might find the IOUs of households-again normally payable in the obligations of financial institutions." [Wray 2015, p-5] Bell argues, "When, for example, the postal service proclaims that a $\$ 0.32$ stamp will be accepted as payment for delivery of a small envelope, an individual/institution must agree to hold the stamp (to accept the stamp as the debt of the postal service) in order for it to become Chartal money." [Bell April 1998, p.6] She continues, "Going back to Keynes, then, a great number of 'things' will answer to the 'description' or 'title' of money. That is, every plane ticket, pre-paid phone card, movie ticket, subway token, etc. is a form of Chartal money. One could anticipate the disaster ahead if we were planning to describe the 'hierarchy of money' in detail." [Bell April 1998, p.7]

However, these things like postage stamp, "every plane ticket, pre-paid phone card, movie ticket, subway token, etc." cannot be treated as any type of money, because according to MMT, "all money is a 'ticket' or 'pay-token' which gains validity by proclamation that it will be accepted as a means of payment. These 'tickets' or 'tokens' which individuals/institutions have proclaimed acceptable as a means of payment do not become money until they have been accepted by another individual/ institution." [Bell April 1998, p.6] However, none of these things ("every plane ticket, pre-paid phone card, movie ticket, subway token, etc.") are accepted by other institutions than the institutions that issued it and, therefore, cannot be treated or accepted as money as Bell wants us to accept.

The MMT is distorting the history of money by suggesting that in modern times state issues money. However, though state used to issue money in the past but that money was either a commodity or token (certificate of commodity). State never issued fiat money that is not a commodity itself or not backed by any commodity. Now-a-days, state does not issue money. Therefore, considering money as a creature of state is a colossal blunder.

The MMT takes double standard in explaining the status of state money (IOU) on one side and other monies (IOUs) that are issued by banks, firms and households, on the other side. MMT argues that the hierarchy of monies of different issuers depends on their convertibility into higher forms of money (IOU). Thus, "To get business and household debt accepted, they might be 
converted into the debt of someone higher in the pyramid." [Bell April 1998, p.8] But, MMT exempted state money from being converted into any money higher in the pyramid of hierarchy, because there is no higher authority than the state that issues its money (IOU). MMT explains that state money does not need conversion into any higher forms of money. According to MMT, the state money, to be accepted, needs the power of the state to pass state's debt to the taxpayers as their tax-debt. Moreover, while other monies are not accepted for payment and medium of exchange, MMT argues that state money, even if it is not convertible, is accepted for payment and medium of exchange. Again, MMT exempts state money from payment of interest. While issuers of other monies (IOUs) must pay interest to the holder of their IUOs, the state is not liable to or must not pay any interest against its money (IOU) to the holder of its IOUs. MMT also argues that other monies (IOUs) cannot be redeemed through payment but can be converted into higher forms of money (IOU). Only the state money can be redeemed through tax payments. Therefore, to be redeemed, the other monies must first be converted into higher forms of money. Thus, MMT takes double standard to pass the state money as an IOU (that cannot be used for full and final payment), and at the same time, to pass the same state money as an instrument that is used for full and final payment. MMT failed to realize that only that money that has its intrinsic value can be used for medium of exchange and full and final payment, but the state money is (according to MMT) is nothing but a numeraire (number) having no intrinsic value. The MMT assigns these dual characters to the state money to establish their theory that state money is nothing but an IOU (debt instrument) of the state and at the same time to pass the state money off as real money (not an IOU) that is used for payment and as medium of exchange. This is a duality or inconsistency on the part of the MMT.

The MMT fails to realize that what they term as money (IOU) issued by issuers of different hierarchy is not money at all; they are IOUs of their issuers. If none of those monies (except the state money) is redeemable or not accepted for payment and as medium of exchange, and if they can be accepted only if they are redeemed into the highest form of money (that is state money) then they can at most be considered as claims (IOUs issued against the state money) on the state money. Besides, in modern economy no entity (even the state) other than the central bank can create money. Therefore, there is no state money as the MMT claims it to be there in a state. The whole foundation (argument) of the MMT that state money is the supreme is a hoax and not a reality. There is only one type of money that is issued by the central bank; and the state, for its spending, depends on the money that it gets through payment of tax and through borrowing money from the citizen (the central bank does no more lends money directly to the government in any country).

Therefore, as there is no money other than the central bank money, so no hierarchy of money can exist.

\subsection{Theory relating to Taxes and Bonds:}

The MMT argues that government creates money and buys goods and services from the people by paying money that it creates. Therefore, the MMT does not think that government depends for its spending on the proceeds from taxation and bond-sale. Stephanie Bell writes, "After carefully considering the complexities of reserve accounting, it is argued that the proceeds from taxation and bond sales are technically incapable of financing government spending and that modern 
governments actually finance all of their spending through the direct creation of high-powered money. The analysis carries significant implications for fiscal as well as monetary policy." [Bell July 1998, p Preface] "Modern governments, then, finance all of their spending through the direct creation of new (high-powered) money." [Bell July 1998, P 22]. Wray argues that government does not need either to tax or sale bonds to be able to spend. "Another shocking truth is that a sovereign government does not need to "borrow" its own currency in order to spend. Indeed, it cannot borrow currency that it has not already spent! This is why MMT sees the sale of government bonds as something quite different from borrowing." [Wray June 2014, p-3] "Government never needs to sell bonds before spending, and indeed cannot sell bonds unless it has first provided the currency and reserves that banks need to buy the bonds." [Wray June 2014, p. 4] "Indeed, if government spends and lends currency into existence, it clearly does not need tax revenue before it can spend. Further, if taxpayers pay their taxes using currency, then government must first spend before taxes can be paid. Again, all of this was obvious 200 years ago when kings literally stamped coins in order to spend and then received their own coins in tax payment." [Wray 2015, p. 2]

However, Wray is wrong when he says that "Note that we still say that we have filed our "tax return" when we pay taxes. What did we "return"? We returned to our sovereign government its own currency (along with a statement showing how much we owed). In the old days, we would "return" to government its coins, tally sticks, paper money, and other forms of currency in order to meet our tax obligation" [Wray 2015, P-2]. Here, the MMT is wrong in understanding that Hazelwood tally sticks were used as money for paying tax to the state. Though term "return' has been used continually from the time of 'tally sticks', yet it is not really return of what we pay as tax; it is paying tax not just returning the government's currency to government. When it was tally sticks, just returning tally sticks would not work, as Wray wants us to believe. What Wray did not explain is that tally sticks would not be accepted as returned unless and until the commodities that were written on the tally sticks were paid to the government. Tally stick was not currency or money which was issued by the government to chosen few who were obliged to pay tax. Names and quantities of commodities, the taxpayers were bound to pay, were written on the tally sticks. Taxpayers would return the tally sticks to check such and such commodities of such and such quantities, as had been written on the tally sticks, had been paid. Tally sticks were only the records of what should be given as tax. Just returning the tally sticks would not mean that taxes were paid. Tally sticks would not have any use other than as fuel after they were returned to the treasury. Those tally sticks cannot be used for a second time. Each time, fresh tally sticks were issued to the taxpayers. Besides, we do not return just currency or money to the government as tax; we transfer our right to the commodities that we could buy with that money or currency to the government. If we pay tax in coins, we transfer our right to the commodity of which the coin is made. If we pay paper money or other forms of money as tax, we transfer to the government our right to that commodity or reserve against which the Money Issue Department had issued that money. What we pay as tax is just not the paper money that has almost no value; we transfer the right to that commodity that we could buy against the face value of the money. Therefore, it is not "returning" of what the government issued as currency or money; it is paying that commodity which we could buy against the money. 


\subsubsection{Tax}

The MMT argues that though for spending government does not need receipts from tax, yet imposition of tax by the state on its subjects has various other purposes.

(A) Taxes redeem the money: The MMT argues that "Government imposes a tax obligation" [Wray 2015, p-5] because, payment through tax is necessary to redeem government's debt obligation that the government itself creates through spending money. "When the sovereign issues currency, she/he becomes a debtor. The sovereign's currency is debt. The holder of the currency is the creditor. The most fundamental promise made by any debtor is the promise to redeem, by acknowledging his/her debt and accepting it. Those who themselves have debts to the sovereign can submit the sovereign's debt in payment." [Wray Nov. 2016, p. 8] "Currency must be debt and it must be redeemed to have a determinant nominal value in terms of the domestic money of account. The sovereign might make other promises when she/he issues debt. There could be a promise to pay interest over time. There could be a promise to redeem her/his debts for the debts of other sovereigns. While uncommon even in history, the sovereign could also promise to redeem for precious metal bullion. These are additional promises but are not necessary to create a demand for the sovereign's currency" [Wray Nov. 2016, p.8] "taxes redeem the currency. All issuers of IOUs must stand ready to redeem them." [Wray, 14 May 2014, p. 3]

However, nowadays, government does not create money. Again, previously, when the government could create money, it would not create money as debt; it would create either commodity money or create token money (paper money) against its bullion reserve it had.

The MMT argues that "It must also be recognized that when currency or reserves return to the State, the liabilities of the State are reduced and high-powered money is destroyed. ... the State, once it fulfills its promise to accept its own money (HPM) at State pay-offices, can eliminate an equivalent number of these liabilities from its balance sheet." [Bell July 1998, p. 21]. "I have argued that the sovereign imposes debts - tithes, fees, fines, and taxes - on the population. Those with tax debts can redeem themselves and wipe clean their tax debt by delivering back to the sovereign her/his tallies, coins, or paper notes. Today it is actually done with keystrokes - debits to private bank deposits and the bank reserves at the central bank." [Wray Nov. 2016, p. 10].

(B) Tax prevents inflation: Another reason of imposition tax obligation, according to MMT, is to reduce inflation. "Taxes remove currency from circulation; this has long been recognized as a way to prevent currency issues from causing inflation. However, it is not necessary to remove all the issued currency through taxes. Some will continue to circulate to facilitate private transactions. Some can be accumulated as net saving. And some can be "redeemed" for bonds should the treasury decide to sell them." [Wray Nov. 2016, p. 9].

However, this argument of MMT is contradictory. If government purchases with its IOU and if purchasing by government is the only way of getting IOUs, then how that purchasing causes inflation. It can only happen if government itself buys goods and services at the price above the normal price. If government purchases are at par the normal price and /or if the purchases are done above normal price, in both cases, it is crime on the part of the government to force the sellers to pay back their hard-earned money to the state as tax, only on the pretext that "Currency must be debt and it must be redeemed" [Wray Nov. 2016, p-8] if there remains no other strong ground for paying tax. 
(C) Tax drives currency: According to Bell, the other reason of imposition of tax liability is "taxes can be viewed as a means of creating a demand for the government's money, HPM." [Bell July 1998, P 20]. "Since it is the law that individuals must pay taxes, they must (assuming they wish to avoid punishment) acquire the State's money. In a sense, the State, unlike any other issuer of promises, can 'force' the acceptance of its liabilities; in order for the taxpaying population to settle their obligations to the State, they must accept the State's money." [Bell April 1998, p. 7]. Wray writes, "MMT says that the main purpose of the tax system is to "drive" the currency. One of the reasons people will accept the sovereign's currency is that taxes need to be paid in that currency. From inception, no one would take currency unless it was needed to make payments. Taxes and other obligations create a demand for the currency used to make obligatory payments. From this perspective, the true purpose of taxes is not to provide "money revenue" that government can spend. Rather, taxes create a demand for the government's own currency so that the government can spend (or lend) the currency." [Wray 2015, p-5] However, Here, Wray is confused when he writes, "taxes create a demand for the government's own currency so that the government can spend (or lend) the currency. Government can spend and it certainly spends; but the government certainly does not lend money.

(D) Tax move resources from private sector to public sector: Another reason for imposition of tax obligation is "We've previously established that "taxes drive money". We've also established that from the perspective of the sovereign that creates the money, the purpose of the monetary system is to move resources to the public sector." [Wray, 17 June 2014, p. 1]. "The purpose of the tax is to free up resources to pursue the public purpose-including anti-poverty programs." [Wray, 02 June 2014, p.3] "But why should the government need to take from the private sector the money (currency and/or bank reserves) that it alone is capable of creating? It seems reasonable to suggest that it is not money but bridges, armies, satellites, etc. that the government wants and that it acquires them by encouraging the population to provide them in exchange for government money. That is, it cannot be the government but the public/citizens who need the money in order to settle their tax liabilities to the state." [Bell July 1998, p. 19]. "In other words, the government's purchase of goods and services using newly-created money must first have supplied the citizens with the means with which to pay taxes. Thus, taxes can be conceived as the means by which the government directs real resources from private to public domain. If this theory is accepted, taxes are used to create a demand for the government's money, not to "finance" the government's spending." [Bell July 1998, p. 19]. "The purpose of taxation is to get people to work and produce for the State. That is, the State wants bridges, armies, etc. and gets the private sector to produce them by imposing taxes." [Bell April1998, p. 4]. "the need to pay taxes means that people work and produce in order to get that in which taxes can be paid" [Minsky 1986, p. 231]. [Quoted in, Bell April1998, p. 5]

(E) Taxes discourage sins: "Taxes can serve other purposes, too, as l've argued earlier in this series. We can use taxes to discourage "sins"-in which case the purpose of the tax is to eliminate "sin" so the optimal sizing of the tax would eliminate sin and hence raise no revenue at all. Previously, I argued that we can view excessive riches as a sort of "sin" that we want to tax away. ... The goal is not to raise revenue but to reduce sin." [Wray, 02 June 2014, p.4] "We've long taxed various sins. While some confuse the purpose of sin taxes, it should be clear that the purpose of taxing bads is not to "raise revenue" but to "reduce sin". We want to reduce the sin of smoking. Of polluting. Of high-speed trading." [Wray 17 June 2014, p. 3] 
L. Randall Wray gives two reasons for why do we need taxes. The first reason is "we have argued that "taxes drive money" in the sense that imposition of a tax that is payable in the national government's own currency will create demand for that currency. Sovereign government does not really need revenue in its own currency in order to spend. ... Spend first, tax later is the logical sequence." [Wray 15 May 2014, p. 1]. "the second reason to have taxes is to reduce aggregate demand. If we look at the United States today, the federal government spending is somewhat over $20 \%$ of GDP, while tax revenue is somewhat less-say $17 \%$. The net injection coming from the federal government is thus about $3 \%$ of GDP. If we eliminated taxes (and held all else constant) the net injection might rise toward $20 \%$ of GDP. That is a huge increase of aggregate demand, and could cause inflation. Ideally, it is best if tax revenue moves counter cyclically-increasing in expansion and falling in recession. That helps to make the government's net contribution to the economy countercyclical, which helps to stabilize aggregate demand." [Wray 15 May 2014, p. 1].

Beardsley Ruml gives four reasons for why we need taxes. Arguing in line with Beardsley Ruml, a New Dealer who chaired the Federal Reserve Bank in the 1940s, Wray writes, "Why, then, does the national government need taxes? He [Beardsley Ruml] counts four reasons: (1) as an instrument of fiscal policy to help stabilize the purchasing power of the dollar; (2) to express public policy in the distribution of wealth and of income as in the case of the progressive income and estate taxes; (3) to express public policy in subsidizing or in penalizing various industries and economic groups; and (4) to isolate and assess directly the costs of certain national benefits, such as highways and social security. (1964, Beardsley Ruml "Tax Policies for Prosperity", pp. 268). Wray explains these four reasons thus: The first of these is related to the inflation issue we discussed above. The second purpose is to use taxes to change the distribution of income and wealth. For example, a progressive tax system would reduce income and wealth at the top, while imposing minimal taxes on the poor. The third purpose is to discourage bad behavior: pollution of air and water, use of tobacco and alcohol, or to make imports more expensive through tariffs (essentially a tax to raise import costs and thereby encourage purchase of domestic output). These are often called "sin" taxes-whose purpose is to raise the cost of the "sins" of smoking, gambling, purchasing luxury goods, and so on. The fourth is to allocate the costs of specific public programs to the beneficiaries. For example, it is common to tax gasoline so that those who use the nation's highways will pay for their use (tolls on throughways are another way to do this)." [Wray 15 May 2014, p. 3]. Wray adds,"It is very common to use wage taxes, sales taxes, profits taxes, income taxes, and wealth taxes in highly monetized economies." [Wray 17 June 2014, p. 2]

\subsubsection{Government Bonds}

MMT explains though government does not need proceeds from bond-sales for its spending, yet bond-sales fulfill various other purposes:

\section{(A)Bond-sale help the Central Bank to maintains positive interest rate on lending}

"Bonds, which are used to prevent deficit spending from flooding the system with excess reserves, allow the maintenance of positive overnight lending rates. Neither taxes nor bond sales, therefore, need be viewed as a financing operation." [Bell July 1998, P 20]. "bonds need not be issued in order to allow the government to spend in excess of current taxation. ... In the absence of bond sales, deficit spending would result in a net increase in aggregate bank reserves. Bonds, then, 
are used to coordinate deficit spending, draining what would otherwise become excess reserves. They provide the private sector with an interest-earning alternative to non-interest-bearing government currency and allow the government to spend in excess of taxation while maintaining positive overnight lending rates." [Bell July 1998, P 19]. "In order to move to a positive funds rate, either the Federal Reserve or the Treasury would be forced to sell bonds to drain excess reserves. Banks, not wishing to hold an excessive amount of non-interest-bearing government money, would be all-too-happy to exchange noninterest- earning reserves for interest-bearing Treasury bonds." [Bell July 1998, P 22].

\section{(B) Government helps people to save their excess money in bonds}

"By definition, the government's deficit (its spending less its tax receipts) must equal the nongovernment sectors' surplus (receipts from government spending less tax payments). In nominal terms, the equation is guaranteed and we can even assert that it is a position that is desired by the nongovernment sector (for otherwise, it would have spent more - reducing the government's deficit - or less, raising the deficit). [Wray Nov. 2016, p. 9] "When government sells bonds, banks buy them by offering reserves they hold at the central bank. The central bank debits the buying bank's reserve deposits and credits the bank's account with treasury securities. Rather than seeing this as borrowing by treasury, it is more akin to shifting deposits out of a checking account and into a saving account in order to earn more interest. And, indeed, treasury securities really are nothing more than a saving account at the Fed that pays more interest than do reserve deposits (bank "checking accounts") at the Fed." [Wray June 2014, p-3] "sovereign governments don't need to borrow their own currency in order to spend! They offer interest-paying treasury securities as an instrument on which banks, firms, households, and foreigners can earn interest. This is a policy choice, not a necessity" [Wray June 2014, p-4]. "Usually the population also wants to save government monetary instruments for uses beyond taxes, so a government ought to run a deficit." [Tymoigne May 2017, p. 10]. "When the nongovernment sector reduces its own spending - perhaps in an attempt to increase its saving - the government's deficit is likely to rise. Indeed, at least to some degree the government's deficit rises until the nongovernment sectors' desire to save has been satisfied." [Wray Nov. 2016, p.9]

(C) Bond-sales help money to be redeemed: MMT argues that like tax, bonds are sold also to redeem the debt of the sovereign government, because when someone buys bonds paying money to the treasury, the money (IOU or debt of the government) is redeemed. Wray writes, "Indeed, currency that is redeemed for taxes or in receipt of bond sales is burned, not spent." [Wray Nov. 2016, p. 9].

However, the MMT is wrong in thinking that returning of money through bond-sales to the treasury redeems the treasury's debt that the treasury has been created itself earlier when it has spent the money by purchasing goods and services. Because, by selling bonds, Government becomes liable to repay the loan with accrued interest at the time the loan matures. Government is bound to make provisions to repay the debt (arise out of government-bonds) when the debt matures. Wray seems to be illogic. He did not justify that if government does not need to sale bonds for spending why then government sales bond when government is bound to repay the loan with accrued interest at the maturity of the bond. 


\subsubsection{Assessment/ criticism of the MMT's explanation regarding Tax and Bonds}

In explaining the purposes of imposition of tax and selling bonds, the MMT has distorted the facts in their own way.

Once MMT argues that government creates money, again he says that the central bank creates money. Wray is confused. Bell writes, "Moreover, the Federal Reserve and/or Treasury, as the only agents capable of supplying them [money], must have been the original source of these reserves [money]." [Bell July 1998, P 5]. However, Bell is wrong. While the government cannot and does not create money, Bell herself accepts that only the central bank creates money when she writes, "Federal Reserve notes (and reserves) are booked as liabilities on the Fed's balance sheet and that these liabilities are extinguished/discharged when they are offered in payment to the State." [Bell July 1998, P.20].

The argument of MMT that, "there is another, more powerful, method by which to argue that taxation and bond sales should not be considered financing operations" [Bell July 1998, P.20] is wrong because Bell herself accepts that the proceeds from taxation and bond-sales are at first deposited in the Treasury and then the Treasury can spend out of that deposit. Bell writes, "There is surely no doubt that the proceeds from taxation and bond sales are deposited into accounts held by the U.S. Treasury (either with commercial banks or at the Federal Reserve) and that the government spends by writing checks on Treasury accounts at Reserve banks. Moreover, since funds are transferred from T\&L accounts to the Treasury's account at the Fed in order to cover anticipated shortfalls in these accounts, it certainly looks as though the government uses these proceeds to finance its spending. This apparent interdependence is, undoubtedly, the basis for the treatment of taxation and bond sales as financing operations." [Bell July 1998, P 18]. Wray also writes, "So, in the US, the Treasury is required to make deposits to its account at the Fed before it can write checks." [Wray March 2014, P.14].

The MMT explains that the government destroys or burns the money that it gets from the proceeds of taxation and bond-sale. Bell writes, "in order to 'get its hands on' the proceeds from taxation and bond sales, the government must destroy the money it has collected." [Bell July 1998, P 21]. "Indeed, both taxation and bond sales lead (ultimately) to the destruction of HPM." [Bell July 1998, $P$ 24]. Wray writes, "Note that tax payment redeems both taxpayer and sovereign. Isn't that nice? The sovereign's currency is burned, and the taxpayer can burn her tax bill." [Wray Nov. 2016, p.10] Wray also writes, "Indeed, currency that is redeemed for taxes or in receipt of bond sales is burned, not spent." [Wray Nov. 2016, p. 9]. However, the MMT is wrong when it argues that receipts from taxation and bond-sales are destroyed or burnt by the Treasury or the government, because the proceeds from taxation and bond-sales are deposited in the Treasury and government spends out of that deposit. Besides, if government really burns or destroys money why it imposes tax and sales bond at all? If the government destroys the proceeds from the bond sales, then how and why government repay the money collected through bond sales along with the interest accrued on it.

In explaining how the liability for money issued by the central bank extinguishes, Bell writes, "Federal Reserve notes (and reserves) are booked as liabilities on the Fed's balance sheet and that these liabilities are extinguished/discharged when they are offered in payment to the State." [Bell July 1998, P. 20]. However, the MMT is wrong arguing that Central Bank's liabilities extinguish through tax payments in currency to the state. What is said to be the central bank's 
liability is shown in the Liability side of the Money (Currency) Issue Department of the Central Bank. There, in the Asset side are the reserves against which the currencies are being issued; the currency, thus, issued are shown in the liability side. Such liability (issued money against the reserve) of the central bank can only be extinguished if the reserve of corresponding value is taken out of the Money Issue Department. Therefore, Bell is wrong when she argues that money (liability of the central bank) is extinguished when money is paid as tax-payment to the state.

The MMT also accepts that the government spending equals to the sum of the proceeds from taxation and bond-sales. Wray writes, "To an uncertain but significant degree, the difference between spending and taxing over any particular period is "endogenously" determined by economic activity. By definition, the government's deficit (its spending less its tax receipts) must equal the nongovernment sectors' surplus (receipts from government spending less tax payments)." [Wray Nov. 2016, p.11] Again, Wray argues that "However, it is not necessary to remove all the issued currency through taxes. Some will continue to circulate to facilitate private transactions. Some can be accumulated as net saving. And some can be "redeemed" for bonds should the treasury decide to sell them." [Wray Nov. 2016, p. 9]. However, these two statements of Wray is contradictory and unintelligible. If government creates money through only buying goods and services and the spending equals to the sum of proceeds from taxation and bondsales, then no money will be left in the economy to make it possible that "Some will continue to circulate to facilitate private transactions. Some can be accumulated as net saving" as Wray (the MMT) claims.

Bell wishes that "Barring self-imposed constraints, the Treasury could manufacture all of its spending balances by selling bonds directly to the Federal Reserve." [Bell July 1998, P 19]. However, the wish of Bell will never be fulfilled, because by selling bonds to the Federal Reserve, government will be indebted to the Fed for the sum of money that it will borrow from the Fed and to make provisions for paying that debt with accrued interest, the government either will need to take more loans from the Fed or to increase taxes. Thus, the constraints is not "self-imposed", it is the bottleneck that is a reality in the economy as it is functioning now. Without wishing that government may borrow as much as it wishes from the Fed, the MMT should find other ways and means so that government needs not to borrow at all.

\subsection{Theory of Functional Finance:}

Wray, the leading theorist of Modern Money Theory argues that "functional finance" approach can serve as the basis of fiscal policy formulation. He writes, "we will show how the "functional finance" approach of Abba Lerner follows directly from MMT. This leads to a discussion of monetary and fiscal policy - not only what policy can do but also what policy should do. Again, the discussion will be general because the most important goal of this Primer is to set out theory that can serve as the basis of policy formation." [Wray 2015, P xi]

According to Wray Minsky was first to formulate "functional finance" theory though he only once had used this term. "I do not recall Minsky ever discussing functional finance inside or outside the classroom. I've only found one use of it in his work - in a 1960 paper." [Wray Jan. 2018, P 6]. In 1943, Abba Lerner wrote an essay entitled Functional Finance and the Federal Debt. Lerner argues that a sovereign government "can adopt what Lerner called a "functional finance" approach to budgeting. What Lerner meant is that the policymaker's focus should be on the 
"functional" outcome of the policy rather than on the budgetary impact" [Wray Jan. 2018, p. 2]. Lerner was seriously concerned with inflation and unemployment - the two major sources of economic ills. Bell writes, "In laying out the theory of Functional Finance in 1943, Lerner clearly believed that two economic ills - inflation and unemployment - had to be repressed if economic insecurity was to be eliminated." [Bell Nov. 1999, p. 13]. "He [Lerner] formulated two principles of functional finance: government should spend more if there is unemployment, and government should supply more money (reserves) if interest rates are too high. ... his admonition [was] that finance should be "functional" (to achieve the public purpose) rather than "sound" (formulated to achieve "balance")" [Wray Jan.2018, p. 8].

Stephanie Bell explains Lerner's disposition on Functional Finance thus: "Lerner proposed his two "laws" of Functional Finance. The first law placed upon the government the responsibility for maintaining the total rate of spending on goods and services at the level necessary to purchase all of the output that it was possible to produce. In elucidating this law, Lerner explained that when spending was at the requisite level it would prevent both inflation and unemployment. In order to manipulate total spending, he suggested that the government increase its own expenditures or reduce taxes so that private spending would increase. Similarly, the government could cut its spending or raise taxes in order to reduce the total rate of spending: "By these means total spending can be kept at the required level, where it will be enough to buy the goods that can be produced by all who want to work, and yet not enough to bring inflation by demanding (at current prices) more than can be produced." (Lerner, 1943, p. 40)" [Quoted in Stephanie Bell, Nov. 1999, p. 2].

"While Lerner did not initially believe that inflation would emerge before full employment had been reached, he later recognized that prices might begin to rise before all resources were fully employed. He noted that: [A]s long as it is possible for the supply of goods to increase along with the increase in spending; there will be no (permanent) increase in prices. (Lerner, 1951, p. 8)" [Quoted in Bell Nov. 1999, p.3].

"Although prices might begin to rise prior to the attainment of full employment, they would not remain high and, thus, should not induce an abdication of the government's responsibilities with respect to the first law of Functional Finance.

"The first law of Functional Finance is designed to eliminate a shortfall in total spending, while the second decrees the specific manner in which the deficiency is to be funded. Specifically, the second law calls for the sale of interest-bearing government debt only in the event that private spending would otherwise generate excessive aggregate demand. Under ordinary circumstances, Lerner argued, it is expected that capitalist economies will suffer from insufficient rather than excessive aggregate demand so that it would not be necessary to offer bonds in exchange for money as a means of tempering inflationary pressures. Instead, Lerner believed that bonds should be sold to the central bank or to private banks "on conditions which permit the banks to issue new credit money based on their additional holdings of government securities, [which] must be considered for our purposes as printing money" (Lerner, 1943, p. 41)." [Quoted in Bell, Nov. p. 3]

"Lerner advocated the printing of money to finance the spending necessary for the maintenance of full employment. Again, the idea is to sell bonds to banks (private banks or the central bank) as opposed to the non-bank public, so that funds which might otherwise be spent are not lured 
away (or "crowed out") by the government. Thus, while most economists would argue that the government should borrow from the public (i.e. sell bonds in exchange for existing money) in order to finance the excess of spending over taxation, Lerner believed that the government should do this "only if it is desirable that the public should have less money and more government bonds" (1943, p. 40)." [Quoted in Bell, Nov. 1999, p. 4]

"How might a country print money in conformity with Lerner's second law? ... In his [Lerner's] view, if private banks are capable of purchasing government debt by crediting a government account, this, too, should be considered printing money. Thus, when either the central bank or a private bank purchases newly-issued government debt by issuing credit or bank money, they are, in effect, printing money." [Bell, Nov. 1999, p. 4].

"if the central bank purchases a newly-issued security from the Treasury, it will do so by crediting the Treasury's account. ... Once the fiscal authority draws on this account in order to acquire goods and services, it can be said to have paid for its purchase by 'printing' money." [Bell, Nov. 1999, pp 4-5].

"Under Lerner's more general definition, however, whenever private or public banks, act "as agents for the government in issuing credit or bank money," they may be said to be printing money for the purposes of government finance (Lerner, 1943, fn., p. 41). Not only can they print money on behalf of the government, but, as dictated by the second law of Functional Finance, Lerner argues that they should do so." [Stephanie Bell, P 6].

However, "In this example, narrow and base money do not each rise by an equivalent amount. In particular, there is no net increase in the quantity of base money as a consequence of the government's spending. This is why economists do not generally refer to this form of government finance as having resulted in the printing of money." [Bell, Nov. 1999, p. 6]

"Lerner unabashedly denied any intelligent grounds for the adoption of so-called "sound" finance: "In brief, Functional Finance rejects completely the traditional doctrines of "sound finance" and the principle of trying to balance the budget over a solar year or any other arbitrary period. In their place it prescribes: first, the adjustment of total spending (by everybody in the economy, including the government) in order to eliminate both unemployment and inflation, using government spending when total spending is too low and taxation when total spending is too high; second, the adjustment of public holdings of money and of government bonds, by government borrowing or debt repayment, in order to achieve the rate of interest which results in the most desirable level of investment; and, third, the printing, hoarding or destruction of money as needed for carrying out the first two parts of the program.(Lerner 1943, p. 41)" [Bell, Nov. 1999, p. 6].

However, Minsky and Lerner both have abandoned their theory of 'functional finance' as this would create big deficits and would be uncontrollable for the government. Wray himself writes, "Minsky appears to abandon functional finance and to adopt the deficit dove (or even deficit hawk) approach. [Deficit hawks want balanced budgets (or even budget surpluses); deficit doves accept budget deficits in recession but want these balanced against surpluses in the upswing (the terminology is credited to Stephanie Kelton). By contrast, deficit owls adopt the functional finance approach.] ... It appears that his views shifted and he took a harder line against big deficits." [Wray Jan. 2018, p. 5]. Wray writes that Minsky was afraid of "if government continues to run deficits even as it nears full employment, the danger of fueling inflation, as well as financial instability, rises. To preserve the purchasing power of bond holders, longer-term interest rates 
would need to rise. That could create a vicious cycle of bigger deficits, more inflation, and then higher interest rates to compensate for the inflation tax." [Wray Jan. 2018, p. 26].

Lerner in his 'Functional finance' approach suggested that government should increase its deficit and spending till full employment is reached. However, Government cannot increase spending causing increase in deficit persistently as it cannot increase tax infinitely to redeem its bonds along with interest in future.

'Lerner [himself rightly] spelled out his opponents' fears regarding [government's]' excessive' indebtedness: "If the interest on the debt must be raised out of taxes . . . it will in time constitute an important fraction of the national income. The very high income tax necessary to collect this amount of money and pay it to the holders of government bonds will discourage risky private investment, by so reducing the net return on it that the investor is not compensated for the risk of losing his capital. This will make it necessary for the government to undertake still more deficit financing to keep up the level of income and employment. Still heavier taxation will then be necessary to pay the interest on the growing debt - until the burden of taxation is so crushing that private investment becomes unprofitable, and the private enterprise economy collapses. (Lerner 1943, p. 44)" [Bell, Nov. 1999, p. 8].

Minsky also abandoned his earlier stand on Functional Finance. Wray writes, "I will note that Lerner also abandoned his simpler functional finance approach in his later work-I think for much the same reason that Minsky had a decade earlier." [Wray Jan 2018, p. 6].

Both Minsky and Lerner realized that "a sovereign government that issues its own currency can never "run out of money"-it can never be forced into involuntary default and it can always make all payments as they come due" [Wray Jan. 2018, p. 2] is not true because government does not print or issue money and that government must repay the deficit using its tax-receipt. "He [Minsky] asserts that government must validate its debt with taxes, and goes on to repeat the common joke that: "Taxes are the price you pay for civilization."' [Wray Jan, 2018, p. 21]. This means that Minsky no longer, in later years, believed that the sovereign can spend money as much as it needs (because its spending is constrained by its only income from tax-receipts and debts due to deficits must be repaid with tax-receipts and tax-receipts cannot be increased without limit and increased expenditure leads to increase in interest rate and inflation).

Wray himself explained that because of the fear of increase in deficits that cause increase in interest rate and inflation, both Minsky and Lerner suggested increase in tax to offset the increase in deficits. Going further from his earlier stance, Lerner even argued later that it would be better to leave demand management to the monetary policy of the central bank than to following a 'functional finance' in fiscal policy. Wray explains their latter stands thus: "Lerner's rejection of his earlier views led him to argue that demand management should be left to monetary policy and placed under the control of the central bank. He argued that any increased government spending needs to be offset by a reduction of spending elsewhere-this could be reduction of some other government spending, but he advocated instead a tax increase that would reduce private spending. Ironically, Lerner replaced functional finance with a sound, balanced budget, finance approach - not because government would run out of money, but because he worried about the inflationary impact. He goes even further than the deficit dove position, for he no longer suggests that the deficit must expand even in recession-on the argument that monetary policy alone could steer the economy. 
This is somewhat in line with what Minsky was arguing-who also feared that fiscal policy had become too biased toward deficits and that debt could fuel inflation because the spending on transfers and interest payments are "inefficient"-although Minsky's views were better grounded in institutional reality, and he never adopted the Monetarist line that the Fed should be responsible for "demand management" through control of the money supply." [Wray Jan. 2018, p. 32]. Bell writes, at first, "he [Lerner] opined that inflation would set in only after the system was pushed beyond full employment. Later, however, Lerner recognized that inflation would begin to set much sooner." [Bell Nov. 1999, p. 13].

However, state cannot print money to increase its spending according to its needs. Wray writes, "The state no longer spent its IOUs, but rather ran its fiscal operations through its central bank, issuing bills, receiving credits to its account, spending central bank IOUs and receiving the same in tax payments." [Wray March 2014, p.27].

Wray is wrong in saying that government expenditure is different from the household expenditure because household cannot create money like the state that can create money. Wray himself writes, "In the late 1960s the microeconomic household budget constraint was applied to government budgets (spending is "financed" by taxes, borrowing, or money printing). We've essentially been stuck with that view ever since. A sovereign's budget is "just like a household's," so it must adopt "sound finance."' [Wray March 2014, p.27].

Therefore, 'functional finance', as advocated by Wray, is not the correct path to solve the problem of financing the government expenditure; it will increase both the government's burden of deficit budget and the inflationary interest rate. To make the 'functional finance' functional, MMT must find a solution how the constraints of increased deficits like rising inflation and interest-rate can be controlled.

\subsection{The Theory of Consolidation between the Central Bank and the Government:}

The MMT clams that it has contributed an original theory called 'Consolidation Theory' that explains that the Government and the CB is consolidated into one unit that is government sector. Other sector is the non-government sector. By 'non-government sector' they only mean the commercial banks as another whole unit. They claim that one should not look into what is going on between the $\mathrm{CB}$ and the Government relating to government's income and expenditure and to who is issuing sovereign currency the government or the CB.

"Perhaps the most important original contribution of MMT has been the detailed study of the coordination of operations between the treasury and the central bank. Central bank is the treasury's bank, making and receiving payment on behalf of the treasury. The procedures involved can obscure how the government "really spends". While it was obvious two hundred years ago that the national treasury spent by issuing currency, and taxed by receiving its own currency in payment, that is no longer so obvious because the central bank stands between the treasury and recipients of government spending as well as between treasury and taxpayers making payments to government." [Wray June 2014, p. 2] Thus the central bank helps the government to execute its fiscal policies. The government also helps the central bank in its monetary policy operations like targeting overnight rates of interest. Wray writes, "MMT recognizes that bond sales by sovereign government are really part of monetary policy operations. 
While this gets a bit technical, the operational purpose of such bond sales is to help the central bank hit its overnight interest rate target (called the fed funds rate in the US). Sales of treasury bonds reduce bank reserves and are used to remove excess reserves that would place downward pressure on overnight rates. Purchases of bonds (called an open market purchase) by the Fed add reserves to the banking system, prevent overnight rates from rising. Hence, the Fed and Treasury cooperate using bond sales/bond purchases to enable the Fed to keep the fed funds rate on target." [Wray June 2014, p. 4]

"The problem is that most people think Fed independence is natural, desirable, and immutable. But in reality, the Fed is a branch of government and a creature of Congress" [Wray March 2014, p.26]. "This paper argues that the Fed is not, and should not be, independent, at least in the sense in which that term is normally used. [because]," [Wray March 2014, p.1] "In the US, the Fed is a "creature of Congress," established by the Federal Reserve Act of 1913 ... Elected officials play a role in selecting top Fed officials. And while the Fed is nominally owned by share-holding banks, and while the Fed's budget is separate, profits above $6 \%$ on equity are returned to Treasury.... Further, as we will see, the Fed's operations are necessarily closely coordinated with the Treasury's; the Fed, after all, functions as the Treasury's bank." [Wray March 2014, p.6] "it [the central bank] is subject to the will of Congress. Further, the Fed cannot really be independent from the Treasury, because the Fed is the federal government's bank, with almost all payments made by and to the government running through the Fed. As such, there is no "operational independence" that would allow the Fed to refuse to allow the Treasury to spend appropriated funds. [Wray March 2014, p.1]

Wray argues that the central bank provides adequate reserves to the commercial banks so that they can buy government bonds selling of which is a necessity to keep on government spending. Wray writes, "Since central bank purchases of securities supply the reserves needed by banks to buy government debt, a virtuous circle is created, so that the treasury faces no financing constraint. ... the central banks are essentially "printing money" to keep sovereign-government borrowing costs low." [Wray March 2014, p.1] Therefore, "We will argue here that the Fed is independent only in a very narrow sense." [Wray March 2014, P.4].

"There [is] a distinction among tools, targets, and goals [of the central bank]. Goals are usually defined in terms of unemployment, inflation, and growth ... the central bank targets an inflation rate that serves as a measure of monetary policy success; employment and output growth are then expected by-products of hitting the inflation target." [Wray March 2014, p.11]

"The old monetarist preference was instead for a quantitative target (reserves) that would allow the central bank to control money growth. That was then supposed to allow the central bank to keep inflation low ... Modern central banks have dropped monetary (quantitative) targets in favor of interest rate (price) targets-both because they are easier to hit and because the current thinking is that they are more reliably linked to the goals." [Wray March 2014, p. 12]. "In practice there are many interest rates, so central banks typically target the overnight interbank rate (fed funds rate in the US) with a view to affecting other market rates." [Wray March 2014, p.11]

"The Treasury and the central bank also work closely in the Treasury's management of its substantial cash payments and withdrawals of Treasury Tax and Loan account balances deposited in commercial banks, since these cash flows affect bank reserves." [Wray March 2014, p.14]. "In practice, the Treasury attempts to maintain a constant (small) positive account balance 
at the Fed, which ensures that fiscal operations do not affect private bank and reserve balances." [Wray March 2014, P.15]. "we presume that the Fed is to cooperate with the Treasury so that the fiscal operations proceed smoothly. ... How do the Treasury and Fed ensure that budget deficits over a time period (spending greater than receipts) do not affect bank reserves and deposits? The key is "debt management": new issues of Treasuries by the Treasury and/or open market sales by the Fed. ... That can be accomplished by selling new Treasuries to banks, which would credit the Treasury's deposits. However, when the Treasury shifts deposits, the Fed needs to debit bank reserves. Since in normal times banks do not operate with excess reserves ... The Fed can either lend the reserves or it can buy Treasuries in open market operations ... it really cannot refuse to supply the reserves [to the banks]. [If the Fed does not supply the banks with reserve and the banks do not have sufficient reserve to buy Treasuries], it would cause the fed funds rate to rise above target. If a central bank targets overnight rates, it must accommodate demand for reserves. In other words, the central bank's "independent" interest rate-setting conflicts with its "independence" from fiscal operations, in the sense that it must provide the reserves banks will need when the Treasury moves the proceeds from a bond sale to its account at the Fed in order to make payments." [Wray March 2014, p.16] [Again], "The Fed's choice is not to refuse to "cut checks" so that the Treasury can spend funds allocated by Congress, but rather to tighten [monetary] policy if it believes fiscal policy is too expansive." [Wray March 2014, p.16] "the Treasury and the Fed cooperate to bring about a fairly high degree of harmony in managing the Treasury's balances at Reserve banks" [Bell July 1998, p. 14]

In defense of the consolidation theory, Bell writes, "Note that the government can deficit spend without taxing or selling bonds first but that if government spending is greater than taxation, the banking system will be left with excess reserves. The Treasury, therefore, prefers to use bonds to coordinate its deficit spending, selling them to Special Depositories (and allowing T\&L credit) before spending from its accounts at Reserve banks. The bonds, then, allow the government to defend (ex ante) the fed funds rate." [Bell July 1998, p. 17]

"When the Treasury does spend these proceeds [from sales of Treasury bonds], the deposits and reserves of banks are restored. At this point, the Fed will need to reverse its previous operation: banks will now have excess reserves that can be drained either through an open market sale of Treasuries by the Fed (that is, the Fed sells the Treasuries it just bought) or the Fed and banks wind down discount window loans. [Wray March 2014, p.17]

"Likewise, the instrument typically used in monetary policy to maintain positive interest rates is treasury debt, not central bank debt." [Wray March 2014, p.20]

"We conclude this section with the finding that the legislated "operational independence" of the central bank is limited in practice because the actual procedures adopted ensure the central bank cooperates with the treasury as it implements fiscal policy." [Wray March 2014, p.20] "Chairman Ben Bernanke has said that "of course we'll do whatever Congress tells us to do": if the Congress is not satisfied with the Fed's actions, the Congress can always tell the Fed to behave differently." [Wray March 2014, p.5] "The problem is that most people think Fed independence is natural, desirable, and immutable. But in reality, the Fed is a branch of government and a creature of Congress." [Wray March 2014, p.26]

"However, the claims for Fed independence are overstated. First, for the reasons discussed above, the Fed must coordinate with Treasury operations to ensure it can hit overnight rate 
targets. Second, the Fed is a "creature of Congress," created by public law that has been amended several times." [Wray March 2014, p. 27] "In conclusion, we see that there is no place in the current operating procedures for the Fed to prevent the Treasury from spending budgeted amounts." [Wray March 2014, p.22]

However, though the MMT claims that "Consolidation Theory" is their original contribution to the study of fiscal and monetary policies of the government and the central bank respectively, yet their original contribution did not help in avoiding constraints in pursuing fiscal and monetary policies. Their original contribution confuses us in understanding what is going on in real economics activities.

It is not that buying and selling of government bonds helps central bank to maintain a positive interest rate target. On the contrary, central bank can increase or decrease the interest rate payable on the government bond. Wray himself writes, "It is true that the central bank can choose to keep the interest rate paid by treasury on its debt higher, or lower, which impacts overall government spending (since interest is a cost covered by spending)." [Wray March 2014, p.20] "the Fed has a great deal of discretion over its setting of the interest rate target. In practice, almost any rate target could be justified as consistent with the goals." [Wray March 2014, p. 12] Wray also accepts that "bonds are not needed ... to help the central bank to hit [interest] rate targets." [Wray 2015, p-4]

Though in the past, government used to buy government bonds directly from the government but, now-a-days, central bank does not buy government bonds directly. [Wray argues that] MacLaury summarizes the evolution of Fed and Treasury sharing of responsibilities as follows: [Until 1951]"Because the central bank supported the market for government securities, it was forced to purchase amounts of securities necessary to maintain low interest rates and the par value of securities. Thus, as the Treasury issued additional debt, the central bank was forced to acquire part of that debt. This process resulted in direct addition to bank reserves. Following the 1951 accord between the Treasury and the Federal Reserve System, the central bank was no longer required to support the securities market at any particular level. In effect, the accord established that the central bank would act independently and exercise its own judgment as to the most appropriate monetary policy." [Wray March 2014, p.13]

Wray is fully aware that, "the central bank of a developed nation is often prohibited from directly financing government budget deficits-as in the US where the FRA mandated a separation of fiscal finances from central bank operations. This is a deviation from the traditional role of the first central banks, which was quite explicitly created to provide state finance." [Wray March 2014, p.14]

The proof that the central bank is independent from government is that, "the Fed's monetary policy is not subject to audit by the Government Accountability Office (GAO)—and courts have refused to hear suits that accuse the Fed of policy mistakes." [Wray March 2014, p.8]

Therefore, issuing of money by the central bank cannot be treated as government money because government just depends on the tax-receipts and on proceeds from bond-sales for its spending. And the Central Bank does not buy government bonds directly from the government. 
Maintaining a positive interest rate is not the end in itself. The aim of maintaining positive interest rate is to keep inflation in check and to help growth in investment, production and distribution. There are many monetary policies, other than purchasing and buying government bonds, that the central bank may use to keep a positive interest rate. Cash Reserve Ratio, Standard Liquidity Ratio, repos, reverse repos, overnight interest rate etc. can be used to reverse or to minimize the effects of either purchasing or buying of government bonds. Wray is fully aware of it. He writes, "Note the Fed for some time has used repos and reverse-repos rather than outright sales and purchases-which ensures actions can be quickly reversed to minimize the Treasury's operational impacts on bank reserves." [Wray March 2014, p.17]

From the above discussion, it becomes clear that though central bank and government co-operate in their monetary and fiscal policies, yet they cannot be consolidated in the same bracket of government sector. The central bank is free from any government control in its monetary policy formulations and government is free from central bank's control in its fiscal policy formulations. The original contribution of MMT in assuming a "consolidation" between the government and the central bank only blurred our vision in identifying and understanding what really monetary and fiscal policies respectively of the central bank and the government are.

However, the MMT knows full well that it is the central bank that creates money and that what is argued as state money is in reality the money of the central bank. "There are two real world complications that require some comment. First, most payments in modern economies do not involve use of a government-issued (state, "fiat") currency; indeed, even taxes are almost exclusively paid using (private) bank money. Second, government money is not emitted into the economy solely through treasury purchases. In fact, the central bank supplies most of our currency (paper notes), and it is the proximate supplier of almost all of the bank reserves that are from the perspective of the nonbanking public perfect substitutes for treasury liabilities." [Wray July 2005, p.17] "the treasury is not the only source of reserve injections or deductions. Central banks principally provide reserves at the discount window or through open market purchases of sovereign debt, foreign currencies, or gold." [Wray July 2005, p.17] "The paper notes are the central bank's liability and the asset of the holder." [Wray Nov. 2016, p.8] "In theory, the government should accept its central bank notes in tax payment" [Wray Nov. 2016, p.8]

However, Wray himself wrote that central bank and the government is separate institutions. He writes, "Now, we recognize that in developed countries today there is a division of responsibilities between the Treasury and the Central Bank and that the Central Bank is in many nations nominally independent of the State. ... with the case of the US-which separates the Fed and Treasury" (Fullwiler, Kelton and Wary, Jan 2012, p. 3) Wray is aware that, the Federal Reserve Act of 1913 legislated the separation of the Treasury and the Central Bank functions.

Wray wishes, "if we simply consolidate the central bank and the treasury, calling the conglomerate "the state", we eliminate many complications. When one uses a bank liability to pay "the state", it is really the bank that provides the payment services, delivering the state's fiat money, resulting in a debit of the bank's reserves. When the state spends, it provides a check that will be deposited in a bank, leading to a reserve credit on the books of the bank. ... only payments to the treasury or cash withdrawals from banks cause a reduction of banking system reserves, while payments by the treasury result in reserve credits.' [Wray July 2005, p.17] This statement Wray clearly proves that what the MMT clams as 'consolidation' is not a reality but mere a fantasy. The MMT 
only hopes, what the monetary and fiscal situation would be if a consolidation between the central bank and the government could be achieved. Therefore, the consolidation has no real existence.

\subsection{Theory of Government is the Employer of Last Resort:}

Pavlina R. Tcherneva argues that as "The private sector is unable to produce and maintain tight full employment over a long run." [Tcherneva April 2018, p. 2] Therefore, government should become the Employer of Last Resort (ELR). The system through which the government will employ all the unemployed will be ELR Program. This is also called as "the Job Guarantee (JG)." "Full employment is defined as a situation where any person of legal working age who wants to work is able to obtain employment at a living wage and decent working conditions." [Tcherneva April 2018, p. 2] Wray claims that "I summarize an employment program that will guarantee true, full employment (or zero unemployment) for all ... Further, the full employment policy would help to reduce economic fluctuation (the "business cycle") through a powerful built-in automatic stabilizer." [Wray June 1998, p.540]

The MMT argues that even government can afford spending to achieve employment for all the unemployed. Wray asserts that "It will be clear that I do not accept such a view-to the extent that sovereign governments operate under financial constraints, these are self-imposed and mostly result from political considerations. Sovereign governments can always financially afford to provide jobs to unemployed workers." [Wray Aug. 2007, p. 21] He suggests that "The ELR program will be financed in exactly the same manner that military spending or Social Security spending or highway spending is accomplished-by crediting bank accounts. If there are limits to government spending (and I [Wray] agree that there are, however, they have nothing to do with financial constraints), they do not result from the method used to finance such spending." [Wray Aug. 2007, p. 23] He wants that the expenses for the Employer of Last Resort Program of the government will be funded by the sin-tax paid by the rich, as the rich have accumulated wealth through the sinful way. He is against taxing the poor. He writes, "It is fitting that those who already enjoy all the benefits of life at the top ought to suffer more when they are sinful. Don't tax the sin of the worker who enjoys the occasional six-pack of brew. Go after the real sinners-those with the wherewithal to engage in truly anti-social sinning-speculative and consumption excess." [Wray, Nov. 2012, p. 18] It is clear that he is not consistent in his arguments. Once, he says that as a sovereign issuer of money the government can spend whatever it needs to spend. Again, he opines that the rich should be taxed.

Besides, Wray's concern for giving employment to the unemployed is half-hearted and halting, it is not "True Full Employment". He suggests minimum wage for the ELR workers and that too will be fixed. According to Hurford and Kaboub, Wray's view is that "The ELR wage can be pegged to the current minimum wage", [Hurford and Kaboub, 2012, p. 22] and that, "in the ELR program, the wage is fixed but the quantity floats". (Wray, Aug. 2007, p. 18) and "This is why "it is probably less disruptive to initially put the ELR wage at the minimum wage". [Wray, Aug. 2007, p. 18] Other MMT economists even want to levy the tax on those who would be employed at the fixed minimum wage. "An income tax of $15 \%$ on this wage would recover $\$ 2,262$ per worker-year, or $\$ 52$ billion over a program that hires all 23 million underemployed." [Hurford and Kaboub, 2012, p. 23] Therefore, the intention of the MMT is not to employ the unemployed fully with all the remuneration and parks that the government employees enjoy. 
However, Wray did neither prescribe any alternative to "accepted economic theory" nor any suggestion alternative to present economic practices that can solve the present impasse of fiscal deficits so that the government may be able to finance employment of all the unemployed. Wray only argues that "debt-ceiling" is a political decision and not an economic one. He argues that even after 50 generations people may opt for more increase in government deficit or debt to continue the ELR program. Thus, he became oblivious of the fact that the government cannot increase its debt that it will not be able to repay at the maturity of that debt. He also argues that sovereign government can spend any amount of money because the government creates money when it spends. This notion is completely false because government does not create money; only the central bank creates money and government depends for its expenditure on tax receipts and on borrowing money through selling bonds both of which the government cannot increase to an infinite amount. He knows it well. That is why he argues that government may increase its deficit to any amount that is sufficient to meet full employment policy. However, he ignores the fact that the government must be capable of repaying its debt at the maturity of the debt. And he did not suggest any means how the government will be able to repay its debt at the maturity of the debt. He only argues, "ELR, by design, ensures that the deficit will rise only to the point that all involuntary employment is eliminated: once there are no workers willing to accept ELR work, the deficit will not be increased further." [Wray June 1998, p. 541]

In his article "zero Unemployment and stable prices" [Wray June 1998, p. 539], Wray claims that ELR Program will not induce price-inflation because "With ELR in place, however, labor is paid for working, which can lead to production of publicly supplied goods and services". What is termed by Wray as "publicly supplied goods and services" is not at all "public", because what the ELR workers will do is to mean "reduce private sector costs (for example, by reducing crime), and can increase the education and skills of ELR workers (compared with education and skill level of the unemployed)." [Wray June 1998, p. 543] Now, spending for ELR workers so that they do not choose to commit crime and that they can enhance their skill only to be employed in private sector later, are not public utility goods or services. However, as "publicly supplied goods and services" does not create any goods and services that can be sold in market, so the wags that the ELR workers will get will be spent in buying goods and services that are mostly produced by the private sector. This will create extra pressure on the supply side of the marketable commodities and thus induce prices to hike.

Wray discarded the same policy of government spending for employment generation advocated by Keynes. He argues, "This stands in stark contrast with "Keynesian" demand management policies that were designed to "prime the pump" with government spending that would increase private demand sufficiently to lower unemployment to the "full employment" level. The danger was that this would lead to such "tight" labor market that inflation would be generated long before reaching full employment." [Wray June 1998, p. 543] The difference between the Keynes' and that of Wray is Keynes like Wary did not suggest that all unemployed must be employed even if deficit rises above government's ability to repay and that like Wray Keynes did not suggest that all unemployed will be paid a fixed minimum amount of wages irrespective of their level of efficiency and experience. "Lerner opposed pump-priming for its formulation often implicitly called for the balancing of the government's budget as an objective goal: a practice which is fundamentally at odds with the theory of Functional Finance." [Bell Nov. 1999, p. 2] MMT is heavily indebted to Lerner's two laws of "Functional Finance" that he advocated in 1943 in his essay "Functional Finance and the Federal Debt". In his first law "What Lerner advocated, in this essay, 
was the maintenance of true full employment" while the second law "decrees the specific manner in which the deficiency [in the budget to maintain full employment] is to be funded. Specifically, the second law calls for the sale of interest bearing government" [Bell Nov. 1999, pp. 2-3] However, in both the cases (Wray's prescription of ELR Program and Keynes' prescription (what Wray calls "prime the pump") of government spending for employment-creation) price positively rises. Wray himself accepts that ELR Program also leads to price-rise. He made a contradictory statement, "In conclusion, ELR is not likely to induce inflation - much less to cause accelerating inflation - even if it does cause prices to rise when implemented and each time the ELR wages is raised." [Wray June 1998, p. 544] Wray himself accepts that "Paradoxically, neither accepted economic theory nor practical experience indicates that high or low full employment is even possible with stable prices."

Wray asserts that "Sovereign governments can always financially afford to provide jobs to unemployed workers." However, Wray himself argues that spending for achieving full employment will increase government deficit/ debt. Wray writes, "We would restate it as follows: tax rates should be set so that the government's budgetary outcome (whether in deficit, balanced, or in surplus) is consistent with full employment. A country like the US (with a current account deficit at full employment) will probably have a budget deficit at full employment (equal to the sum of the current account deficit and the domestic private sector surplus). A country like Japan (with a current account surplus at full employment) will have a relatively smaller budget deficit at full employment (equal to the domestic private sector surplus less the current account surplus)." [15 May 2014, p. 4].

Therefore, MMT's policy proposals for "True Full Employment" or "Job Guarantee" through "Employment of Last Resort Program" is also contradictory and confusing and unrealistic.

\section{An Assessment of Modern Money Theory}

From the above discussion it is conclusively proved that the earlier money-theories on which the MMT is based have contradictions in analyzing what really money is and are not based on reality. As MMT is founded on those wrong theoretical arguments, so, their explanations and conclusions about money, monetary and fiscal theories are also not rational and not founded on solid realistic analysis. In this section, I will discuss the following reasons for why and how the MMT is misguided. MMT wants that all unemployed should and must be employed by the state as private sector cannot ensure full employment in the present capitalist system. To enable the government to spend as much as is needed for achieving full employment, MMT needs a theory that government can create money. However, in making such a theory, MMT needs to declare money is not a commodity. Because if money is pegged to any commodity then the government is bound to acquire that commodity before it can issue any money and then the government's power of creating as much money as it needs will be constrained by the ability of the government to acquire that much commodity. Therefore, the MMT needs to invent a theory that the government creates money out of nothing or from thin air. However, MMT faced a real difficulty in establishing this theory; that is, if government can create money out of nothing then why the government must impose tax. The MMT knows very well that in reality government depends on tax receipts and on proceeds from bond-sale. Therefore, MMT needs a theory to combine both their new theory of creation of money by the government from thin air and the reality that government depends on 
tax and borrowing. Therefore, MMT invented another theory that government creates money out of nothing as debt and that debt must be redeemed by tax payment to the government. Why government must levy tax; the MMT invents another theory that to make government's money and to reduce inflation government should impose tax. Thus, the MMT tries to establish a theory that money is nothing but debt (of the government) and that the debt-money is nothing but a record of the amount of debts and credits. The MMT did not bother to ask or clarify debts or credits of what, they simply by-passed this question by stating the money is merely a numeraire or a debt (monetary/ financial instrument) instrument on which debts and credits are recorded. To establish their theory that money is nothing but a debt instrument, they invented or imposed a theory that in modern capitalist economy exchanges are being done using only debt-money or financial instruments. Again, to establish this theory on the historical foundation, the MMT invented or claimed that never was there any commodity-money, even if money was full-bodied gold or silver coin. Thus, MMT's explanation of money and its origin is biased in the sense that MMT did not try unearthing/ unfolding how and why money has been evolved. They admit that they want to explain money and its origin according to what they formulated as essential characters of money, i.e., money is a debt (financial instrument) having only records of debts \& credits and no intrinsic value of its own.

Now, let us see exactly what explanations the MMT gives. MMT argues that it is impossible to trace the history of origin of money. "To be sure, the history of money is "lost in the mists of time," as money's invention probably pre-dates writing. Further, the history of money is contentious."'Wray May 2012, p.3] Besides, MMT argues that we are not clear how we will identify a thing as money. MMT writes, It has long been speculated that money predates writing because the earliest examples of writing appear to be records of monetary debts-hence, we are not likely to uncover written records of money's "discovery". Further, it is not clear what we want to identify as money." [Wray July 2005, p.1] The MMT does not agree to the Orthodox economists' view that money is commodity that is used as medium of exchange. The Orthodox view, as Samuelson explains, is "Inconvenient as barter obviously is, it represents a great step forward from a state of self-sufficiency in which every man had to be a jack-of-all-trades and master of none.... If we were to construct history along hypothetical, logical lines, we should naturally follow the age of barter by the age of commodity money. Historically, a great variety of commodities has served at one time or another as a medium of exchange: ...tobacco, leather and hides, furs, olive oil, beer or spirits, slaves or wives...huge rocks and landmarks, and cigarette butts. The age of commodity money gives way to the age of paper money.... Finally, along with the age of paper money, there is the age of bank money, or bank checking deposits. (Samuelson 1973, pp. 274-6)" [Quoted in Wray May 2012, p. 2]

"The orthodox economist views our economy as a more-or-less free market economy in which ... money is used primarily to facilitate exchange of real goods, undertaken by self interested maximizes for personal gain." [Wray May 2012, p.5] However, the MMT discarded this view of the Orthodox economists arguing that "The orthodox explanation of the origins of money is based on the existence of an economy based on barter exchange in formal markets (the fairground barter) which predates the introduction of "money." But this is neither historically accurate, nor is it coherent. The institutional prerequisites to the development of market exchange include the existence of private, alienable property, recognition of individual responsibility, self-interested behavior, and forward-looking production. Yet, the historical examples of barter exchange used to justify the traditional approach rarely show any of these characteristics. This paper will argue 
first that primitive "exchange" or "barter" did not lead to the development of markets; second, that money did not develop out of primitive "exchange;" third, that both "fiat money" and "credit money" predated coined "commodity money;" and fourth, that the quantity of credit money has never been constrained by the quantity of central bank liabilities, as in the "multiplier" story." [Wray May 2012, p.9]

The MMT argues that as the Orthodox view cannot explain the origin of money fully and as the MMT itself cannot explain the origin of money because "To be sure, the history of money is "lost in the mists of time"', therefore, the MMT argues that we should formulate an idea about the nature and function of the money that the modern capitalist system is using. They argue that it will be judicious to search the origin of money in the light of the nature and function of money in the capitalist system. The MMT writes, "There is probably no single source for the institution of modern capitalist economies that we call "money"'” [Wray July 2005, p.1]. "More importantly, trying to uncover "the" origins of money is almost certainly an impossible or at least misguided endeavor unless it is placed within the context of a theoretical framework." [Wray July 2005, p.1] The MMT writes, "Given the embedded nature of economic phenomenon in prior societies, an understanding of what money is and what it does in capitalist societies is essential to this approach. This can then be contrasted with the functioning of pre-capitalist societies in order to allow identification of which types of pre-capitalist societies would use money and what money would be used for in these societies. This understanding is essential for informed speculation on the origins of money. [Wray May 2012, p.1] "The comparative approach used by heterodox economists begins with an understanding of the role money plays in capitalist economies". [Wray May 2012, p.2] "If one can develop an understanding of economic phenomena of a capitalist economy, one may use the comparative method to develop an understanding of pre-capitalist economies and improve one's understanding of the capitalist economy." [Wray May 2012, p.7] "an understanding of what money is and what it does in capitalist societies is essential to this approach. This can then be contrasted with the functioning of pre-capitalist societies in order to allow identification of which types of precapitalist societies would use money and what money would be used for in these societies. This understanding is essential for informed speculation on the origins of money." [Wray May 2012, p.8]

The MMT explains that modern capitalist economy does not use money for exchange of goods and services. MMT writes, "An identical economy [capitalist economy] is then hypothesized that does not use money. These are then "compared" to discover why money was invented." [Wray May 2012, p.8] The MMT explains how "money should be defined. In this [MMT] approach, money cannot be identified by its peculiar individual physical "characteristics" (malleable, durable, transportable), nor by its functions (transactions medium, means of payment, etc.). Rather, money is defined with respect to the operation of the economy as a whole. Money is identified as a unit of account; it becomes the social measure of value in all monetary economies. It is an abstract "measuring unit."' [Wray May 2012, p.8]

Thus, the MMT tries to establish that for an exchange, what is used is not commodity money but the debt instrument (IOU or financial instrument, MMT calls it as 'monetary instrument' also) in the capitalist economy and that purpose of any economic activity is only to obtain and amass credits (debt dominated assets or financial instruments or IOU). The MMT writes, "In a monetary economy, the purpose of production is to obtain money-denominated assets; this can be contrasted with a "barter" economy." [Wray May 2012, p.8] The MMT argues that what is used in 
modern capitalist system is not commodity-money but mere a number (numeraire) having no intrinsic value and only a promissory note (IOU or financial or monetary instrument). They distinguish these two things thus: "It is necessary to distinguish between money as a measuring unit and those assets denominated in the money of account. Thus, bank deposits are not money, but are denominated in the social unit of account-that is, money (the dollar in the US). Similarly, it is necessary to distinguish between money and those various functions performed by assets denominated in the unit of account: money is not what money does." [Wray May 2012, p.9] They clarify their understanding of modern money thus: "Some money-denominated assets function as media of exchange or means of payment. While these functions are typically fulfilled by certain money-denominated assets, this does not make any particular asset that so functions money." [Wray May 2012, p.9]

Thus, with the help of their own concocted theory of money of capitalist system, the MMT begins to explain the history of the origin of money. As the MMT concludes that money is nothing but debt-instrument, so they begin to assert that money originated only as debt-instrument in the primitive days and this debt-instrument nature of money is continued till to modern capitalist system. The MMT explains that the monetary instruments that were and are used for exchange is nothing but an instrument of forward contracts or loan. The MMT writes, "Thus, the earliest form of economic exchange produced forward contracts which, in the extreme, took the form of debt bondage in which the "debtor initially rendered himself in the power of the creditor as a debt serf and the creditor at any time during the credit term could call upon the debtor-even up to his extermination"' [Wray May 2012, p.13]. Therefore, according to MMT, "The origins of money are not to be found, then, in a hypothesized exchange society based on barter. Instead, money develops as a unit of account, or, as the terms in which debts are written: "A money of account comes into existence along with debts... Money proper in the full sense of the term can only exist in relation to a money of account." (Keynes 1971, p. 3) When private loans are made, the lender gives up private property in exchange for an IOU issued by the debtor, which represents a forward contract. This private contract must include an interest premium. ... Thus, all forward contracts involve "wheat now for more wheat later" propositions, which are monetary propositions, with money serving as a unit of account." [Wray May 2012, p.15] Thus, the MMT concludes that the history of evolution of money (that was used in the past and is used at present) should be explained in the light of the role that the modern money plays in the capitalist economy as merely an instrument of loan or forward contract, i.e., "money now for more money later". The MMT writes, "By distinguishing money from the various functions it performs, we may conclude that primitive, pre-private property economies did not use money. It is thus an inappropriate use of the comparative method to try to find objects that fulfill "money-like" functions in tribal societies and then label these "money." Rather, our understanding of the role money plays in capitalist economies enables us to use the comparative methodology to identify the contrasts between monetized economies and those based on communal, reciprocal relations - the latter do not use money, although we may find objects that superficially appear to fulfill some of the functions we now associate with assets denominated in the money of account." [Wray May 2012, p.16] "Thus, capitalist production always involves "money now, for more money later." The market, then, "is not a place of barter...but a place for earning the means of settling debts, i.e. money" (Heinsohn and Steiger 1989, p. 193)." [Wray May 2012, p.16] "While many economists (and historians and anthropologists) would prefer to trace the evolution of the money used as a medium of exchange, our primary interest is in the unit of account function of money. Our alternative history will locate 
the origin of money in credit and debt relations, with the unit of account emphasized as the numéraire in which credits and debts are measured. The store of value function could also be important, for one stores wealth in the form of others' debts. On the other hand, the medium of exchange function and the market are de-emphasized with regard to money's origins; indeed, credits and debits can exist without markets and without a medium of exchange." [Wray July 2005, p.2]

Thus, the MMT clearly confesses that whatever may be the history of origin of money, they only wants to define money as nothing but debts in forward contacts. They cannot accept that money originated as commodity money, because then their purpose of establishing money as debtinstrument will not be fulfilled. The MMT argues that means of exchange was/ is always a unit of account (only number/ unit of debt) and not commodity-money, even if this unit of account may take the form of commodity. The MMT writes, "In summary, money first existed as a unit of account. ... The first standardized money of account was wheat, but it was subsequently replaced by barley. Money, recorded as a debt denominated in a unit of account, would be created as part of a forward debt contract. Money acting as a medium of exchange or means of payment would take a physical form (wheat or barley, and later, clay tablets, wooden tally sticks, metal coins, or paper IOUs), denominated in terms of the idealized money of account. Because production in a market system is always monetary production, its purpose is to realize production in money form. Thus, the purpose of production in a "market" economy is to accumulate money-denominated units of the social measure of wealth. Accumulation of money-denominated assets becomes the universally recognized path to wealth; the money of account becomes the social unit of value." [Wray May 2012, p.20]

Thus, MMT reduced money (that was/ is nothing but commodity-money or token or certificate of commodity) to mere written record of debts or credits in number of units) having no intrinsic value, i.e., a numeraire only. However, the MMT is misled. Money was/ is not just a number only; it was either any commodity (gold, silver or any commodity that was/ is accepted as medium of exchange) or token or certificate of commodity that is measured in numbers or units. Besides, money was/ is not a debt or credit; exchanging money with some commodity leaves neither the seller nor the borrower as lender or borrower; the exchange becomes full and final as both that were/ are being exchanged are commodities of equal value. Therefore, money was/ is neither only a number ("unit of account" or "money of account") and nor a record of forward contract or debt. However, one may/ might borrow or lend money (money by nature is commodity) using a instrument of debt or forward contract (the MMT wrongly calls it monetary instrument) that is a record of lending and borrowing of commodity-money and not of any debt instrument.

\subsection{Wooden tally sticks, metal coins, or paper IOUs were/ are not debt-instruments:}

MMT wrongly considers wooden tally sticks, metal coins, or paper IOUs as debts (financial or monetary instrument). MMT writes, "Money acting as a medium of exchange or means of payment would take a physical form (wheat or barley, and later, clay tablets, wooden tally sticks, metal coins, or paper IOUs), denominated in terms of the idealized money of account." [Wray 2012 May, p. 20] Now, let us explain whether these things were/ are debt-instruments or not. 


\subsection{A. Wooden Tally Sticks were not debt-instruments:}

Wray argues that at first, the Kings used to receive tax, fines, tithes, rents, tributes and fees through in-kind payments. Later, Kings changed their mode of tax-receiving. Kings' treasuries began to keep accounts of all these receipts (of tax, fee, fine etc.) in units (Wray calls it 'money unit'). Wray writes, "Palaces created the money unit to simplify accounting." [Wray July 2005, p. 8]. Wray argues that thereafter, Kings began to issue wooden tallies (instrument of tax obligation) to his tax payers. He writes, "Once a money rent, tax or tribute was levied on a village, and later on individuals, the palace would be able to obtain goods and services by issuing its own money denominated debt in the form of tallies." [Wray July 2005, p.8] Wray explains why the Kings began to use tallies thus: "While government could in theory require [tax] payment in the form of all the goods and services it requires, this would be quite cumbersome. Thus it becomes instead a debtor to obtain what it requires, and issues a token (hazelwood tally or coin) to indicate the amount of its indebtedness; it then accepts its own token in payment to retire tax liabilities." [Wray July 2005, p. 10] Here, Wray is confused when he argues that coin issued by the ruling authority (the king) is a debt-instrument and that government's ability to force its citizens to be [tax] debtor and to pay tax in that coin. The fact is that governments in olden days used to both collect tax and issue coins; coins were not issued as sovereign debt and taxes were not collected only in coins. Wray writes, "most tax collections brought in far more hazelwood tally sticks than coins." [Wray Nov. 2016, p.4] This is because tally-sticks were the records of how much of what commodity should be paid by the holder of those tally sticks and coins were not records of debt or tax and therefore, were paid as tax. Tally sticks were not paid as tax but were brought only to ensure (match) that all taxes were paid in full.

Citizens might pay tax both in coins and in kinds. Hazelwood tally was not used as money for payment in any exchange. Hazelwood tally was the instrument in which it was written who will pay tax in what quantity of which commodity. Just returning of tally sticks to the king would not retire one's tax obligation; returning of tally sticks would mean that so and so commodities that were written on the tally stick had been paid to the treasury. Therefore, tally stick was neither a debt of the government nor an instrument of debt that the tax-payer would owe to the government; the taxpayer would not have any debt to the government because the government had not given him anything earlier.

Wray is misled by wrong theories formulated by some earlier economists. Quoting Innes he writes "Just like any private individual, the government pays by giving acknowledgments of indebtedness-drafts on the Royal Treasury, or some other branch of government. This is well seen in medieval England, where the regular method used by the government for paying a creditor was by 'raising a tally' on the Customs or some other revenue-getting department, that is to say by giving to the creditor as an acknowledgment of indebtedness a wooden tally. ((Innes, 1913, p.397-8)" [Wray July 2005, p. 9] Citing this quotation, Wray wants to make us believe that the government would exchange its "wooden tally" as its IOUs ("acknowledgment of indebtedness") to the sellers from whom the government would buy some goods or services. However, Wray is wrong in considering those wooden tallies as money (or according to Wray a monetary instrument) because those tallies were not used as IOU (monetary instrument) to buy anything but were given to those from whom government wanted to get tax payments. The quotation that Wray uses in favour of his argument proves that those tallies were instruments in which it was written what thing in what quantity should be paid by the chosen tax-payer. Quoting Innes, Wray 
writes "The government by law obliges certain selected persons to become its debtors. It declares that so and- so, who imports goods from abroad, shall owe the government so much on all that he imports, or that so-and-so, who owns land, shall owe to the government so much per acre. This procedure is called levying a tax, and the persons thus forced into the position of debtors to the government ... When these are returned to the government Treasury, the taxes are paid. ((Innes, 1913, p.398) [Wray July 2005, p. 9] Here Wray clearly accepts that those wooden hazelwood tallys, in which payable taxes are written, are issued to the tax-payers. Tallys comprised of two parts called "the stock and the stub" in both of which was written who would pay how much of what commodity to the government. When the receiver (or the chosen taxpayer) of the tally-stick would return the tally stick to the exchequer (tax receiving office), then his tax (according to Wray debt) would be redeemed. However, just returning tally-stick would not redeem the tax-liability of the tax-payer to the King, as Wray wants us to believe. Return of tally stick must be accompanied by the commodities of the same weight and quantity as was written on the tally stick. Therefore, tally-stick was carried to the exchequer not for the purpose of paying tax with it, but to check whether all the commodities (or wealth) that were recorded on it were really paid or not. In that case tally-stick was merely a record of wealth that was to be paid as tax and was neither an instrument of debt nor an instrument with which taxes were paid.

Wray quotes Innes "[p]ractically the entire business of the English Exchequer consisted in the issuing and receiving of tallies, in comparing the tallies and the counter-tallies, the stock and the stub, as the two parts of the tally were popularly called, in keeping the accounts of the government debtors and creditors, and in cancelling the tallies when returned to the Exchequer. It was, in fact, the great clearing house for government credits and debts. (Innes, 1913, p. 398)" [Wray July 2005, p. 9]

The taxpayers were not debtors because they did not owe anything to the government, because government had not given him anything earlier. Certain persons are chosen by the government to pay tax to the government; that is why the taxpayer is giving the tax. Besides, "the Exchequer" was not "the great clearing house for government credits and debts", because the Exchequer does not act as clearing house of debts and credits; it only collects taxes and sees whether all taxes are collected or not.

Wray is wrong when he argues that tally sticks were used as money and that taxes were paid in tallies (as money). Quoting Innes Wray writes, "Innes went on to note that the vast majority of revenues collected by inland tax collectors in England were in the form of the exchequer tallies: [p]practically, the entire business of the English Exchequer consisted in the issuing and receiving of tallies, in comparing the tallies and the counter-tallies, the stock and the stub, as the two parts of the tally were popularly called, in keeping the accounts of the government debtors and creditor “(Innes 1913, p. 398)" [Wray July 2005, p. 9]. The above quotation clearly tells that the tallies were the written description of how much of what commodity should an individual taxpayer should pay to the government. Each tally differed from other tallies in their description of taxes. Therefore, tallies could not be used as money as Wray wants us to believe. Taxes were also not paid by returning the tallies only. Returning of tallies must be accompanied by the same amount of same commodities that were written on the tallies. Therefore, tallies were used to collect tax and neither used for buying goods and services nor used as medium of exchanges. 
One other thing should be noted here. If tally sticks were issued to only those who were chosen taxpayers, then it is certain that tally sticks were not used by the government for buying goods and services. The fact is that government would buy goods and services by using money that the governments minted. Therefore, tally stick (instrument of recording tax) is not the same as money (minted coin). Records of what are to be paid as tax (tallies), therefore, are neither debt instruments (either of the government or of the taxpayers) nor money.

Payment of taxes were made not with monetary instruments like tally sticks; taxpayers used to pay tax mostly in kinds like grains, cattle and other products and commodities and less in coins. Tally sticks were carried to the exchequer only to match with the 'stub' (the counterpart of the 'stock') to compare whether all things that were mentioned in both stock and stub are paid in full as tax to the exchequer. "The sticks were split into stock and stub, matched at the time of redemption and then destroyed." [Wray Nov. 2016, p.4]

Wray wrongly argues that Hazel-wood tally sticks circulated as means of exchange instead of money. Wray himself accepts that these were records of debt. "Tally sticks were commonly issued for hundreds of years in Western Europe - by Kings but also by others as records of debt" [Wray Nov. 2016, p.4]. The way the tally sticks were created also does not prove Wray's assertion that tallies were used as medium of exchange. A. M. Innes, from whom Wray got this idea, writes, "For many centuries, how many we do not know, the principal instrument of commerce was neither the coin nor the private token, but the tally ... a stick of squared hazel-wood, notched in a certain manner to indicate the amount of the purchase or debt. The name of the debtor and the date of the transaction were written on two opposite sides of the stick, which was then split down the middle in such a way that the notches were cut in half, and the name and date appeared on both pieces of the tally. The split was stopped by a cross-cut about an inch from the base of the stick, so that one of the pieces was shorter than the other. One piece, called the 'stock,' was issued to the seller or creditor, while the other, called the 'stub' or 'counter-stock,' was kept by the buyer or debtor. Both halves were thus a complete record of the credit and debt and the debtor was protected by his stub from the fraudulent imitation of or tampering with his tally." [Innes 2004, pp. 32-33] [Quoted in Wray Nov. 2016, p. 4] If "a stick of squared hazel-wood, notched in a certain manner to indicate the amount of the purchase or debt, the name of the debtor and the date of the transaction were written on two opposite sides of the stick, which was then split down the middle in such a way that the notches were cut in half, and the name and date appeared on both pieces of the tally." and "One piece, called the 'stock,' was issued to the seller or creditor, while the other, called the 'stub' or 'counter-stock,' was kept by the buyer or debtor", then this tally cannot be circulated as medium of exchange in trading, because tallies carried different names, different descriptions of debt and cannot be "homogenous" as Wray argues "The sticks circulated because this debt was "homogenous", unlike the debt redeemed by the cloakroom that takes the form of your specific coat. " [Wray Nov. 2016, p. 4]

There were two types of tallies: one type was issued by the King to his tax-payers mentioning on it the commodities that the tax-payer would pay when he would return the tally to the King's payoffice for matching the commodities with the description on both parts of the tally, a stock and a stub. Therefore, tallies issued by the King was not at all a debt-instrument of the king; they are records of what the tax-payers would have to pay; and tax is not certainly a debt, it is a fee for the services that the King gave to his subjects. Other types of tallies were kept by an individual creditor and his debtor so that descriptions of debt could not be tempered and for maintaining the record 
of debt that the debtor owed to the creditor. These types of private tallies cannot be exchanged hands as amount of debt and the names of debtor and creditor were written on them.

Wray also accepts that there were two types of tally-sticks when he writes that "Tally sticks were commonly issued ... Kings but also by others as records of debt." Following passages from Wray are the proofs that merchants also used to issue tally-sticks for commercial purposes. These passages are:

"The merchants would keep a running tally for customers, which would be settled later (usually at harvest). For example, tallies of debts for beer consumed would be kept, with the tally settled at harvest by delivery of barley at the official price and measured in the money of account." [Wray July 2005, p.8] "This [Hazelwood tally stick] was a 'stick of squared hazel-wood, notched in a certain manner to indicate the amount of the purchase or debt' created when the 'buyer' became a 'debtor' by accepting a good or service from the 'seller' who automatically became the 'creditor'. 'The name of the debtor and the date of the transaction were written on two opposite sides of the stick, which was then split down the middle in such a way that the notches were cut in half, and the name and date appeared on both pieces of the tally'. The split was stopped about an inch from the base of the stick so that one piece, the 'stock' was longer than the other, called the 'stub' (also called the 'foil'). The creditor would retain the stock (from which our terms capital and corporate stock derive) while the debtor would take the stub (a term still used as in 'ticket stub') to ensure that the stock was not tampered with. When the debtor retired his debt, the two pieces of the tally would be matched to verify the amount of the debt." [Tymoigne \& Wray 2005 July, p.8] "A merchant holding a number of tally stocks of customers could meet with a merchant holding tally stocks against the first merchant, 'clearing' his tally stub debts by delivery of the customers' stocks. In this way, great 'fairs' were developed to act as 'clearing houses' allowing merchants 'to settle their mutual debts and credits'; the 'greatest of these fairs in England was that of St. Giles in Winchester, while the most famous probably in all Europe were those of Champagne and Brie in France, to which came merchants and bankers from all countries"' [Wray July 2005, p. 8].

Therefore, Wray wrongly argues that "the tally sticks circulated". However, it was not the tallies (either issued by the King or issued by any private individual) but the coins that used to be circulated in trading exchanges. Therefore, Kings' tallies were instruments for keeping records of the payable taxes (not IOUs of the Kings) and the merchants' tallies were the IOUs of the borrower merchants given to the seller (creditor) merchants. Neither the Kings' tallies nor the merchants' tallies could be used as medium of exchange as Wray tries to make us believe.

\subsection{B. Coins were/ are not debt-instruments:}

"To sum up the argument to this point, early money units appear to have been derived from weight units which may have developed from the practice of wergeld. Palaces created the money units to simplify accounting. They also had to establish price lists to value items in the money of account. Initially all of this may have been only to facilitate internal record-keeping, but eventually use of the internal unit of account spread outside the palace. Commercial transactions, rent payments, and fees, fines, and taxes came to be denominated in the money of account. Use of the money of account in private transactions might have derived from debts owed to the palaces. Once a money rent, tax or tribute was levied on a village, and later on individuals, the palace would be able to obtain goods and services by issuing its own money denominated debt in the 
form of tallies. Coins came much later, but were, like the tallies, evidence of the Crown's debt." [Wray July 2005, p. 8]

Wray argues, "Coins ... were, like tallies, evidence of Crown's debt." [Wray July 2005, p.7] He writes, "Innes argued that ' $[\mathrm{t}$ ] he coins which [kings] issued were tokens of indebtedness with which they made small payments, such as the daily wages of their soldiers and sailors' (Innes, 1913, p. 399). This explains the relatively large value of the coins - which were not meant to provide a medium of exchange, but rather were evidence of the state's debt to 'soldiers and sailors'. The coins were then nothing more than 'tallies' as described above - evidence of government debt." [Wray July 2005, p.10] "Even a gold coin really was a debt of the crown, with the crown determining its nominal value by proclamation and by accepting it in payment of fees, fines and taxes at that denomination." [Wray July 2005, p.13] "we argued that coins were nothing more than tokens of the indebtedness of the Crown, or, later, the government's treasury" [Wray July 2005, p. 16]

"The sovereign spent coins into circulation, then accepted them alongside tallies in tax payment". [Wray Nov. 2016, p. 5]. Tallies were records of due-taxes; therefore, after redemption (payment of taxes in kinds that were described in the tallies, the tallies were burnt. However, coins were not a debt (Wray mentions that 'the coin by itself contained all the evidence of the crown's debt' [Wray Nov. 2016, p.5]) of the king; therefore they were not burnt (or destroyed) after tax was paid in coins; they were kept for re-use at a later date. While the tallies were redeemed, coins were not redeemed [Wray argues that, "When it received coin in tax payments, it held them until an announced redemption day, to exchange for paper notes." [Wray Nov. 2016, p.7]); coins were paid to redeem the tax (or a debt). Wray writes, ".Note also that when the King accepted these in tax payments, he was also "redeemed". The tally sticks would be burned (wiping his own debt clean) while coins could be stored for reuse, or melted for re-coining." [Wray Nov. 2016, p.5]

Wray wrongly argue that coin is a debt-liability of a government when he writes, "What is a coin? It is stamped evidence of the Treasury's debt." [Wray Nov. 2016, p.9] Wray himself writes, "While the US Treasury accounts for coins as "equity", equity is of course on the liability side of the balance sheet." [Wray Nov. 2016, p. 9] However, coin is not a liability (debt) because it is circulated at par its face value and because it is a commodity and commodity cannot be a debt. Government also does not treat coins as its liabilities.

"Coins were evidence of debt that solved the problem of counterfeiting not through splitting a notched stick but rather through the technology of stamping or, later, milling coins. High quality craftwork and then milling the edges made "fraudulent imitation" more difficult. In addition, the use of precious metals (which were more easily monopolized by the sovereign) made counterfeiting more difficult and more expensive. The sovereign spent coins into circulation, then accepted them alongside tallies in tax payment. Coins circulated more freely than tally stocks because the coin by itself contained all the evidence of the crown's debt (in the case of a tally stick one needed both the stock and the stub). In addition to promising to take back coin token debts, the sovereign issuer could also promise to exchange them for foreign currency or for precious metal on demand. This is an additional promise added to the promise to accept the coin in payment of taxes. Even without this additional promise, the tally and coin tokens would circulate because they could be used to redeem tax debts. Note also that when the King accepted these in tax payments, he was also "redeemed". The tally sticks would be burned (wiping his own debt clean) while coins could be stored for reuse, or melted for recoining." [Wray Nov. 2016, p. 5] 
"Now, what were coins? As Innes emphasizes, coins were never very important - in spite of all the ink spilled in writing about them. They are essentially metal tallies that can last a long time and still garner interest when discovered centuries after being lost and forgotten." [Wray Nov. 2016, p.4]

"What then are coins, what are their origins, and why are they accepted? Coins appear to have originated as 'pay tokens' (in Knapp's colourful phrase), as nothing more than evidence of debt. Many believe that the first coins were struck by government, probably by Pheidon of Argos about 630 BC (Cook, 1958, p. 257). Given the large denomination of the early coins and uniform weight (although not uniform purity - which probably could not have been tested at the time), Cook argues that "coinage was invented to make a large number of uniform payments of considerable value in a portable and durable form, and that the person or authority making the payment was the king of Lydia' (Cook, 1958, p. 261). Further, he suggests 'the purpose of coinage was the payment of mercenaries"' [Wray July 2005, pp. 9-10]

"What are the implications of this for our study of money? In our view, coins are mere tokens of the Crown's (or other issuer's) debt, a small proportion of the total 'tally'-the debt issued in payment of the Crown's expenditures." [Wray July 2005, p. 10]

Wray is wrong when he asserts that government issued its IOUs so that taxpayers might pay tax in that government's IOUs. Wray quotes Redish who wrote, "[Kraay (1964)] suggested that governments minted coins to pay mercenaries only in order to create a medium for the payment of taxes' (Redish, 1987, pp. 376-7). [Wray July 2005, P-9] Wray also writes, "The key is debt, and specifically, the ability of the state to impose a tax debt on its subjects; once it has done this, it can choose the form in which subjects can 'pay' the tax. While government could in theory require payment in the form of all the goods and services it requires, this would be quite cumbersome. Thus it becomes instead a debtor to obtain what it requires, and issues a token (hazelwood tally or coin) to indicate the amount of its indebtedness; it then accepts its own token in payment to retire tax liabilities. Certainly its tokens can also be used as a medium of exchange (and means of debt settlement among private individuals), but this derives from its ability to impose taxes and its willingness to accept its tokens, and indeed is necessitated by imposition of the tax (if one has a tax liability but is not a creditor of the Crown, one must offer things for sale to obtain the Crown's tokens)." [Wray July 2005, p. 10] Form these two citations above it appears that Wray wants us to believe that the government paid the sellers with government's IOUs and that the taxpayers used those government IOUs to pay their taxes. However, Wray himself contradicts this argument when he asserts that government issued those IUOs to its soldiers who could produce those IOUs to the government's exchequer to get commodities against those IOUs. Wray quotes Cook, "Many believe that the first coins were struck by government, probably by Pheidon of Argos about 630 BC (Cook, 1958, p. 257). Given the large denomination of the early coins and uniform weight (although not uniform purity - which probably could not have been tested at the time), Cook argues that 'coinage was invented to make a large number of uniform payments of considerable value in a portable and durable form, and that the person or authority making the payment was the king of Lydia' (Cook, 1958, p. 261). Further, he suggests 'the purpose of coinage was the payment of mercenaries' (Cook, 1958, p. 257)." [Wray July 2005, p. 8-9]. This quotation clearly proves that coins were issued not for providing means to taxpayers to pay tax but as a medium of exchange with which people could buy things from the royal treasury or elsewhere. In line with 
Crawford Wray argued that those coins (IOUs according to Wray) were used as medium of exchanges when he writes "Crawford has argued that the evidence indicates that use of these early coins as a medium of exchange was an 'accidental consequence of the coinage', and not the reason for it (Crawford, 1970, p. 46)." [Wray July 2005, p. 9]. This means that coins were used as medium of exchanges.

Coins were paid neither as a 'government's debt' to the sellers from whom government would buy goods nor as an obligation of debt for the taxpayers. But, coins that derived its value from its metal content were issued as medium of exchanges (not just as only a numeraire having no intrinsic value of its own as Wray wants us to believe). Therefore, the instruments of tax payments (generally in-kind payments) and medium of exchange (money) are different and not the same thing as Wray wants to make us accept. Therefore, Wray is wrong when he writes, "Certainly its tokens can also be used as a medium of exchange (and means of debt settlement among private individuals), but this derives from its ability to impose taxes and its willingness to accept its tokens, and indeed is necessitated by imposition of the tax (if one has a tax liability but is not a creditor of the Crown, one must offer things for sale to obtain the Crown's tokens)." [Wray July 2005, p.10] Wray is also wrong when he writes, 'money' "are never pure assets but are always debt instruments - IOUs that happen to be stamped on metal" [Wray July 2005, p.12] because neither the tally sticks, records of debt or payable tax (Wray tells these were monetary instruments) nor the coins were a debt of either the government or the taxpayers.]

Therefore, Wray's assertion that "Similarly, we argued that coins were nothing more than tokens of the indebtedness of the Crown, or, later, the government's treasury ... even though coins were long made of precious metal" [Wray July 2005, p. 16] is wrong.

Wray is also wrong when he argues that "The higher the probability of default by the sovereign on his debts (including coins and tallies), the more desirable was an embodied precious metal to be used in recording those debts. In other words, coins with high precious metal content would be demanded of sovereigns that could not be trusted. This probably explains, at least in part, the attempt to operate gold (or silver) standards during the transition from monarchies to democracies that occurred with the rise of capitalism and the modern monetary production economy. Unfortunately, this relatively brief experiment with gold has misled several generations of policymakers and economists who sought the essence of money in a commodity-precious metals_and ignored the underlying credits and debts." [Wray July 2005, pp. 11-12]. Here, Wray is misled as he thinks that "The higher the probability of default by the sovereign on his debts" induced the government to make full bodied coins (metallic value is same as the face value). The government did not create coins as its debt but for using the coins for purchasing goods and services. "The higher the probability of default by the sovereign on his debts" did not induce the government to make full bodied coins (metallic value is same as the face value), but because the reduced value of coins would/ could not be sold at par the face value. This was the reason why government was forced to make gold-coins or accept gold standard. This very misunderstanding led Wray to write "Even a gold coin really was a debt of the crown, with the crown determining its nominal value by proclamation and by accepting it in payment of fees, fines and taxes at that denomination." [Wray July 2005, sp. 12] 
Again, it is not the fact that only the ruling authority could mint money. There were many private moneyers who could mint coins and their coins were universally accepted by the people because the coins were traded/ exchanged at par the value of their metal content. Later, the ruling authority made contracts with those moneyers to make uniformity among all types of moneys according to their metal content and value. Wray also accepts that private coinage was in abundance in every country when he writes "After private coinage was forbidden, the right to coin was usually delegated to private masters that worked under contract (Boyer-Xambeu et al., 1994, p. 45)" [Wray July 2005, p. 11] and when he quotes Quigguin, "Every local borough could have its local mint (Quigguin, 196?, pp. 57-58)" [Wray July 2005, p. 11].

Coins of the olden days would derive their value from their metal content and if coins were debased or short of weight the ruling authority would take steps punishing those who were guilty of such crimes. Quoting from Quigguin, Wray writes "The coins were rude and clumsy and forgery was easy, and the laws show how common it was in spite of penalties of death, or the loss of the right hand. ... [Henry I] decided that something must be done and he ordered a roundup of all the moneyers in 1125. A chronicle records that almost all were found guilty of fraud and had their right hands struck off. Clipping was commoner still, and when (down to 1280) the pennies were cut up to make halfpennies and farthings, a little extra clip was simple and profitable. [...] Clipping did not come to an end before the seventeenth century, when coins were machine-made with clear firm edges [...]. (Quigguin, 196?, pp. 57-58)" [Wray July 2005, p.11] Thereafter, Wray himself writes "Thus, kings actively fought any alteration of the intrinsic value of coins which represented an alteration of the homogenous monetary system that they tried to impose. This preoccupation also fueled the belief that intrinsic value determines the value of money." [Wray July 2005, p.11] However, Wray is wrong when he argues that "the belief that intrinsic value determines the value of money" and "In our view, coins are mere tokens of the Crown's (or other issuer's) debt, a small proportion of the total 'tally'-the debt issued in payment of the Crown's expenditures." [Wray July 2005, p. 9] It is neither a "belief" but is a reality that coins derive their value from their metal content, nor is correct that coins are "Crown's debt". The coins issued by the Crown and the coins issued by the private moneyers both were made of precious metal and would be accepted at par their metal content; therefore, those coins cannot be treated as debt, because when commodity (metallic coins) were used in exchange of some commodity, the values of both coin and the commodity equals and full and final payment is made leaving neither the seller nor the buyer as debtor.

Wray is inconsistent and his arguments are contradictory. Wray himself accepts that coins were circulated at par their metallic value and that debt would be settled in coins. He writes, "Perhaps coins existed before these tallies (records of debts), and surely the coins were made of precious metals. Perhaps the debts were made convertible to coin, indeed; perhaps such debt contracts were enforceable only in legal tender coin. If this were the case, then the credits and debts merely substituted for coin, and net debts would be settled with coin, which would not be inconsistent with the conventional story according to which barter was replaced by a commodity money (eventually, a precious metal) that evolved into stamped coins with a value regulated by embodied precious metal." [Wray July 2005, p. 9] and "Certainly its tokens can also be used as a medium of exchange (and means of debt settlement among private individuals.)" [Tymoigne \& Wray July 2005, p.11] "Part of the appeal of precious metal coins was no doubt the fact that they would have value outside the sovereign's domain." [Tymoigne \& Wray July 2005, p. 11] This is an acceptance 
on the part of Wray that money is commodity-money made of precious metal. and not a monetary instrument that is an IOU or debt instrument (not money).

From the above discussion, it clearly reveals that coins were /are not debts of its issuer (either the King or the private bankers). Coins were/ are commodity-money; it does not derive its value from any proclamation of either the King or the bankers but from the value of its content commodity.

\section{1.C. Paper-notes were / are not debt-instruments:}

Wray wrongly argues that "money is the creature of the state" and an IOU of the state. However, though state could create money, other private institutions like bank also could create money. Therefore, money was not the creature of the state only. It was also not an IOU of the state. Nowadays, government does not create paper notes. Wray himself writes, "Treasury Money" is now mostly coins; in the past treasuries issued notes (and some still do) and while the US Treasury could issue notes, it now only issues coins" [Wray Nov. 2016, p.9]. Only the central bank creates paper notes as its liability against the reserve in its asset side. However, central bank treats paper notes as its assets (not as IOUs of itself) when it gives loan. Therefore, it is also not a debt-instrument or debt either of the central bank or of the government.

Wray is wrong when he writes, "The paper notes are the central bank's liability" [Wray Nov. 2016, p. 8] to mean that paper-notes are debts (IOUs) of the central bank. However, paper-note is liability of the central bank in the sense that if the paper-notes are presented to the central bank by the holder of the paper-note for conversion, then the central bank is liable to give the holder that portion of its reserve that equals to the value of the paper-note. Here, Central bank is not a debtor but acts as safe-keeper of commodity money against which the paper-note has been issued.

Wray also wrongly asserts that government creates and spends its own currency and that taxpayers use the government's currency to redeem their tax-debt. "In theory, the government should accept its central bank notes in tax payment." [Wray Nov. 2016, p.8] and "The first central banks were explicitly created to issue notes to finance government spending, with the notes collected in tax payment." [Wray Nov. 2016, p. 8]. However, Wray himself accepts that this is not true when he writes, "For the most part, treasuries no longer spend their own currency (coins, notes, tallies) into existence, and taxpayers do not pay taxes with treasury's currency" [Wray Nov. 2016, p.9]

Wray also wrongly argues that "The paper notes were thus "redeemed" in two ways: payment of taxes, or exchanged for coin." [Wray Nov. 2016, p 7] However, repayment with paper note helps redemption of taxes or debts, not redemption of itself. Paper notes cannot be redeemed through payments of debt or taxes (or payment in an exchange or payment in various kinds of fees; what can be redeemed are tax-liability and debt liability (instrument). Paper notes can only be redeemed if the reserve, against which it is made of, is paid to the holder of the paper note. Paper notes can be destroyed only if the reserve of the issuer of the paper note is reduced in same amount, because it is the central bank who creates paper-note.

Therefore, contrary to Wray's assertion, paper-note is not debt either of the central bank or of the treasury (government) and cannot be redeemed through payment of tax to the treasury (government). 
However, after all these explanations of how money is originated in the light of MMT's own characterization of money used in modern capitalist economy and arguing that it is not commodity money but the debt-instrument (money of account) that was/ is used in exchange of goods and services, the MMT submits that, "To conclude our introduction, we return to our admission that it is not possible to write a definitive history of money." [Tymoigne \& Wray July 2005, p. 3]

\section{Conclusion / suggestion:}

From the above discussion, it is clear that the theory of MMT does not reflect the fact. Their assertions are nothing but fantasies. Their arguments are contradictory and full of untruths. MMT is misled because of their failure to understand how the economy is really functioning. It will be relevant to identify those areas of misunderstanding and explain them correctly. They are:

\subsection{Government does not create money:}

MMT argues that government creates money (debt-instrument of forward contract) when it spends to buy goods and services. Wray is wrong when he writes, "The paper notes are the central bank's liability" [Wray Nov. 2016, p.8] to mean that paper-notes are debts (IOUs) of the central bank. However, paper-note is liability of the central bank in the sense that if the paper-notes are presented to the central bank by the holder of the paper-note for conversion, then the central bank is liable to give the holder that portion of its reserve that equals to the value of the paper-note. Here, Central bank is not a debtor but acts as safe-keeper of commodity money against which the paper-note has been issued. Wray also wrongly asserts that government creates and spends its own currency and that tax-payers use the government's currency to redeem their tax-debt. However, Wray himself accepts that central bank and not the government that issues money. He writes, "For the most part, treasuries no longer spend their own currency (coins, notes, tallies) into existence, and taxpayers do not pay taxes with treasury's currency" [Wray Nov. 2016, p.9] and "In theory, the government should accept its central bank notes in tax payment." [Wray Nov. 2016, p.8] and "The first central banks were explicitly created to issue notes to finance government spending, with the notes collected in tax payment." [Wray Nov. 2016, p.8] As government can issue only coins it cannot create money and spend through keystrokes and thus create its debt on its own; tax payments by money also does not redeem the government's debt and the money does not extinguish through tax-payments. As government does not create money (as its debt) so it cannot exchange its debt (money) for gold or foreign currency. Therefore, Wray is wrong when he writes, "Affordability is not the problem. A sovereign government can always afford to spend more. Like the American colonies - which authorized more spending financed by paper notes - today's government can spend more using key-stroked entries into balance sheets. This spending increases government's debts, recorded as credits to recipient accounts." [Wray Nov. 2016, p.9] The fact is that the central banks creates money and injects money into the economy as loan. Government imposes tax and sells bonds and spends the proceeds from these two sources.

\subsection{Tithes, Fees, Fines, and Taxes imposed by the government are not debts:}


Wray writes, "I have argued that the sovereign imposes debts - tithes, fees, fines, and taxes - on the population." [Wray Nov. 2016, p.10] However, tithes, fees, fines, and taxes are not debts. Fines are punishments for doing any wrong. Tithes, fees and taxes are payments against services that we receive. Against the payments of tithes we get religious services. We pay fees against some services. Against tax-payment, government gives us protection, maintains law and order and does various public works.

\subsection{Government cannot burn money that it receives as tax:}

Wray writes, after tax payment is made, "The sovereign's currency is burned, and the taxpayer can burn her tax bill" [Wray Nov. 2016, p.10]. However, the government does not and cannot burn money, because the government needs it to spend for purchasing goods and services. Money is extinguished only if it is consumed or no longer used as medium of exchange.

\subsection{Money and Monetary Instrument (forward contract or debt instrument) are not same:}

Minsky, from whom Wray got the idea that there exists no 'money' but 'monetary (debt) instrument', is confused. Once he differentiates between money and lending; in another time, he equates money with lending. He differentiates money with lending when writes, "Loans represent payments [certainly of something, in this case money] the bank made for business, households and governments in exchange for their promises [IOU or monetary instrument or debt] to make payments [certainly of something, in this case money] to the bank at some future date" ((Minsky, 1986, 230). Minsky clearly states that when a borrower of a bank presents a check in another bank, "For member banks of the Federal Reserve System, the interbank payments lead to deposits shifting from the account of one bank to the account of another at Federal Reserve banks." (Minsky, 1986, pp. 230-1) [Quoted in Wray, March 2014, p. 20] This means that the deposit money (not the lending instrument) is shifted from one bank to the other bank and only the lending instrument is destroyed but the money is transferred and not destroyed. Another time, Minsky equates money with lending [act of financing] when he writes "Money is unique in that it is created in the act of financing by a bank and is destroyed as the commitments on debt instruments owned by banks are fulfilled. Because money is created and destroyed in the normal course of business". (Minsky 1986, p. 249) Form these two quotations it clearly appears that the agreement of loan (or debt), not money, is destroyed when the loan is repaid with the money; and money (that has been lent) is returned to the bank. Wray could not understand this ambiguity of Minsky. Therefore, he, without identifying the contradiction in Minsky, made serious mistake by accepting (or equating) money with debt instrument what he calls 'monetary instrument'. 


\section{5. "Money now for more money later" and not "Money (money of account or debt instrument) now for more money (money of account or debt instrument) later" is the motto for business or production activities:}

Wray writes, "The monetary production economy ... is dominated by a complex web of financial relations that were characterized by Minsky as "money now for money later" propositions. (Minsky 1986 p. 228) ... the money of account and those credit-debt relations are the key institutional relations of the capitalist economy." [Wray March 2014, p.11] Here, "money" does not mean commodity money but "money of account". However, it is not true that businessmen want to acquire only more IOUs (money of account) and not wealth. To acquire more "money of account", one should lend more and more. However, businessmen will not just go on lending without redeeming the "money of accounts" in the form of commodities. Therefore, Wray's argument is wrong.

\subsection{Debt or forward contract is also a form of barter exchange:}

Ingham writes, "[M]edia of exchange cannot evolve spontaneously through repeated barter exchanges into monetary systems in which debts are expressed in units of abstract value and settled by means of final payment/settlement of debts that represent quantities of the same value." (Ingham 2013b, p. 126) [Quoted in Wray March 2014, p. 23 -26] Here, Ingham is misled. He understands barter exchange with commodity (commodity may take the form of money if it is universally accepted as the means of final and full payment) and exchange through deferred payments (using the debt instruments) are different. However, both exchange of commodities and deferred exchanges are the two forms of barter. In both cases full and final payment is made only by exchanging commodity or certificate of commodity (that is token money; it may be paper money or e-money or some basest metal. In an instant (or direct exchange) exchange, commodities are exchanged instantly; in an deferred exchange, the debtor (who cannot pay any commodity instantly) makes payment at a later date or time. Only difference is that the creditor may or may not ask or charge for some extra commodity (or commodity money or a token or representative money and not a debt instrument) as interest for the period of delayed payment. Besides, if exchanges are not made in commodities (commodity may be commodity money), then what is being lent or borrowed and with what the final payment will be made.

\subsection{Repayment of bank loans and payment of tax are not same:}

Ingham writes, "In monetary systems, it is the obligation of the issuer of money - bank, treasury, etc - to promise to accept that which it has issued as the final settlement of any debt owed to it." (Ingham 2013b p. 128) [Quoted in Wray March 2014, p. 23 -26] However, it is wrong to equate tax payments with loan repayment. Government does not issue money. Government spends money to buy goods and services. It does not give loan. Therefore, tax payment is not like loan repayment. Tax is paid against the services we get from the government. Though banks issue money it does not buy. Bank lends. The borrower repays the loan with interest. Therefore, payment of tax is not repayment as in the case of loan repayment. 


\subsection{Money is not an IOU:}

Money is not a debt (money of account, financial instrument) instrument of its issuer. The MMT wrongly asserts that paper-note was/ is really the debt-instrument of its issuer (MMT wrongly thinks state is the sole issuer of paper-money, while the fact is that only the central bank has the authority to create paper-money). However, paper-notes both issued against reserve of corresponding value in the olden days and issued against reserve of government bonds nowadays were/ are not debt instrument or forward contracts as the MMT claims it to be. In the past, paper-notes were issued against corresponding reserve of bullion (mainly gold and silver) as token or certificate of the reserve. The paper-notes are, thus, bears the right to the bullion (commodity-money). Therefore, the central bank (issuer of paper-money) is not a debtor; it is the safe-keeper of the commodity-money. If central bank would be a debtor then the central bank should give interest to the holder of the paper-money. But, the central bank does not give any interest to the holder of money. Therefore, paper-note is not the debt-instrument of its issuer central bank. The MMT misunderstood the act of creation of paper-money against governmentbonds (which is nothing but mere papers having no intrinsic value) as money-creation out of nothing and the money as fiat-money. However, if money is created out of nothing or against any government bond having no intrinsic value, then the fault lies with the issuer central bank that is creating money fraudulently. However, whether money is backed by anything of intrinsic value or not, the borrowers (because money enters the economy only when central bank lends money) are indebted the same. The borrowers are equally liable in both cases to repay their loan with accrued interest. The argument of MMT, that the central bank (according to the MMT's "consolidation theory that central bank is the part of the government) creates money as a debt from out of thin air is wrong. The central bank does not create money out of nothing; it creates money against government bonds which the issuer of paper-money central bank thinks to be sufficient reserve against the money it issues.

\subsection{Money is not just a numeraire:}

Wray writes, "We thus conclude this story about the origins and nature of money. ... Monetary instruments are never commodities, rather, they are always debts, IOUs, denominated in the socially recognized unit of account. Some of these monetary instruments circulate as "money things" among third parties, but even "money things" are always debts-whether they happen to take a physical form such as a gold coin or green paper note." [Wray July 2005, p. 19] Wray also writes, "The money of account is chosen by the sovereign and used to denominate debts, prices, and other nominal values. It is the Dollar in the US. It is like the inch, the pound, the meter, the kilogram, the acre or the hectare-a unit of measure. Mat [Mat Forstater] puts it this way: the sovereign can no more run out of "money" than it can run out of "acres" or "inches" or "pounds". We can run out of land, but we cannot run out of acres. We can run out of trees but we cannot run out of the linear feet we use to measure them. You cannot run out of a unit of measure! The "dollar" is the measuring unit in which we keep our monetary records. We cannot run out." [17 June 2014, Wray, Tax Bads, Not Goods, p. 1] However, money (what the MMT terms as "money of account") is not just a number. A 10 dollar note represents relative unit values of every commodity. It represents that a portion of a commodity, value of which is equal to the face value of the dollar. With a 10 dollar note, one can buy 10 sandwiches or 5 oranges or 1 cake. Therefore, it is not value free; it represents this or that commodity (though not a single or specific commodity). 
Initially, it represents that commodity against which it is made or with which it is exchanged. Then it is used as a medium of exchange on the basis of the value of the commodity which is being exchanged and whose value equals to its face value. Every time it is exchanged, it represents the commodity against which it is exchanged.

\subsection{Money is an instrument with which full and final payment is made:}

Anything (material or abstract) that has a direct or indirect bearing on the human race is wealth. Commodity is that wealth that has been marketed for sale or purchase. Money is that commodity which is universally accepted as medium of exchange along with for consumption. Money is that commodity with which full and final payment is made.

\subsection{Government does not print money:}

Wray is confused whether government prints money (that is lending form the central bank) or just credit the accounts of the banks. Hurford \& Kaboub quotes that Wray is of the opinion that, "With functional finance, sovereign governments do not finance projects with taxes or bonds, but rather finance projects through printing money (Wray 1998, p. 4)." (Hurford \& Kaboub, 2012, p. 23) In anther writing, regarding the issuance of new money, Wray gives contradictory statements. He writes, "the fear that government might "print money" if the supply of finances proves insufficient is exposed as unwarranted" (Wray, Oct. 2009, P 10) as "Modern sovereign nation do not "print money" - they credit bank accounts." (Wray, Aug. 2003, P 4)He argues, "It is commonly believed that if the government runs a deficit, it must "borrow" or "print money" to "finance" the deficit spending. This cannot apply to a sovereign nation. A sovereign nation spends by creating bank accounts, or by cutting treasury checks (which then leads to a reserve credit when the check is "deposited"). Whether or how much the government collects as taxes is not relevant to its spending. The implication of a budget deficit, as we saw ... is that bank reserves increase." [Wray, Aug. 2003, p. 3] However, Wray is wrong. As government can issue only coins it cannot create money and spend through keystrokes and thus create its debt on its own.

\section{12. The MMT failed in suggesting a ration explanation of the definition and the origin of money:}

It has become clear that as there is no universally accepted rational definition of money so the MMT tries to impose certain characteristics (that according to the MMT, the modern money bears) on money. Then the MMT rewrites the origin of money's history in a way that conforms to their own created definition of money, completely disregarding whatever the real history of money might be. However, what characteristic the MMT imposes on modern capitalist money is an imaginary one. According to the MMT, money is monetary instrument that is an IOU and used only for forward contract and not used for a settlement of full and final payment. It is a deception on the part of the MMTists who swear that they will find the real definition of money. They willfully distorted the definition and origin of money. 


\section{13. The net private saving does not equal to the government's net deficit spending:}

The MMT argues that the government will increase its deficit till saving appetite of the people is satisfied, because by selling government bonds government helps people to save. However, the MMT is wrong. People do not lend (save) their money only to the government but also to the banks. People also invest their savings in shares, bonds, real estates, businesses and keep some money in their wallets. Therefore, it is wrong to argue that net private savings equals to the net government deficit.

\section{14. The MMT miserably failed to enable government to achieve full employment:}

The MMT's primary goal is to achieve full employment. To help the government to find funds sufficient to reach full employment, the MMT concocted a theory that money is a debt-instrument and that government may create money out of thin air and spend as much as it needs to employ all unemployed persons. Therefore, the MMT suggests not to be worried if deficit-spending increases. On the other hand, they suggest that increase in deficit leads to increase in wealth of those who saves or invests in government bonds. But they are wrong. Government cannot increase its deficit to the extent that will be sufficient for achieving full employment because government is bound to pay the principal and the interest on its debt and it is impossible for the government to repay that amount of debt. Without making provision how government will repay its loan, the MMT argues that government should increase its deficit till the full employment is reached. Therefore, the MMT failed in providing a sound theory of "alternative money" and in providing a sound source of funds for achieving full employment.

From the above discussion, it becomes clear that MMT is misled due to its misunderstanding and misinterpretation of different economic phenomena (discussed above). It also becomes clear that the theories of MMT (credit theory of money, state theory of money, hierarchy of money, consolidation theory, functional finance, theories regarding tax and bonds, and government as the employer of last resort etc.) that have been discussed earlier were impractical, contradictory and fantasies. Therefore, MMT, though cherished to provide an alternative theory of money, has miserably failed to provide a rational and reasonable alternative theory of money or of the evolution of money and monetary system. They failed because they characterized money in their own way and then began to explain the origin of money in the light of their own understanding of money.

\section{This paper adds new ideas to existing knowledge relating to money, monetary and fiscal policies:}

The modern money theory is gaining ground among the economics policymakers' circle. Therefore, it becomes incumbent on the part of a researcher to assess whether the MMT has contributed any new theory or policy that may help to achieve uninterrupted economic growth along with rational \&more efficient production and distribution systems. However, from the critical assessment of the MMT, above, it emerges that the MMT is miserably failed to suggest any alternative policy or theory to that effect. The MMT is not really is in search of the origin and characteristics of money. What it wants is to re-interpret the history of money according their 
incorrect definition of money. The try to reduce even commodity-money which is exchanged at par its intrinsic value to the position of a debt-instrument. The principal defect in the monetary system is that money enters into the economy as loan from the central bank. Without going to solve this defect, the MMT argues that money must be nothing but debt in nature. Besides, MMT created more confusion in understanding what money is and how the monetary and fiscal policies are being pursued. They argue that government can spend without caring for increasing debt (deficit), bonds are not liability of the government but asset of the buyer (holder) of bond, government do not need tax and bond-sale for its spending purposes, commercial banks can create money out of nothing and so on. This paper categorically identifies the contradictions in their arguments and explanations. The purpose of this paper is to make of the readers familiar with the irrational and impractical propositions of the MMT. The MMT is nothing but a fantasy.

\section{Limitation of My Findings:}

I have tried to assess almost all the assertions or theories that are specialties of the MMT brand. However, I may miss or overlook certain points that need to be assessed.

However, it is necessary is to define money and to trace its origin, but I have not tried to do that exercise, because the aim of this paper is only to make an assessment of what the MMT is or stands for. I have avoided suggesting what should be the rational definition of money and how money can be created so that government does not have to take loan and sufficient money may be available for achieving full employment.

\section{References:}

Adak, Naba Kumar and Arabinda Patra (Ed.) (2015). Traditional Practices and Theories regarding Monetary and Fiscal Matters should be replaced by New Policies to overcome the Systemic Errors in the Economic Activities so that World may be Saved from Continuous Economic Deterioration in Evolution of Money and the Question of Its Representative Character, Kunal Books, New Delhi

Adak, Naba Kumar (July 2016). Lessons of Dos and Don'ts from the Quantitative Easing Policy Period $s(2008-2014)$ of the Federal Reserve Bank in the USA, Canadian International Journal of Social Science and Education-www.ocrd-ontario.org

Adak, Naba Kumar (Oct.2016a). Proper Definition of Money is Necessary to Eliminate Business Cycles and Achieve Sustainable Economic Growth, Proceedings of 6th Global Business and Finance Research Conference, Taiwan, http://www.worldbizins.org/img/1499922068.pdf

Adak, Naba Kumar (Oct. 2016b). A Critical Assessment of 'A Meme for Money' written by L. Randall Wray Proceedings of $6^{\text {th }}$ Global Business and Finance Research, Taiwan, www.worldbizins.org/img/1499921846.pdf

Adak, Naba Kumar (Dec. 2016a) - Caste System in India: A Unique Wisdom to Resolve Problems like Barter, Distribution and Unemployment, Proceedings of World Business and Social Science Research Conference 9 - 10 December 2016, Ambassador Hotel, Bangkok, Thailand ISBN: 978-1925488-22-7 
Adak, Naba Kumar (Dec. 2016b). Debt is not Money, Proceedings of 14th Asian Business Research Conference, Dhaka, https://wbiworldconpro.com/pages/paper/dhaka-conference-2016/4195

Adak, Naba Kumar (Dec. 2016c). I Owe You (IOU) is Not Money, Proceedings of 14th Asian Business Research Conference, Dhaka - https://wbiworldconpro.com/uploads/dhaka-conference2016/management/1500346176.pdf

Adak, Naba Kumar (April 2017a). The Central Bank fraudulently creates money out of nothing but pushes it into the economy as if the money is representing some commodity, Proceedings of Conference, Tokyo, https://gribaconfo.com/wp-content/uploads/2017/05/215-Naba.pdf

Adak, Naba Kumar (April 2017b). The "True Full Employment" Prescribed by the Modern Money Theory is neither "True" Nor "Full" and nor "Employment", Proceedings of Tokyo Conference, https://gribaconfo.com/wp-content/uploads/2017/05/216-Naba.pdf

Adak, Naba Kumar (Aug. 2017). Banks Cannot Either Multiply or Increase the Amount of Money or Create Deposits Without Backing of Matching Reserve; Only Central Bank Creates Money, Proceedings of the Conference held in Vienna, International Institute of Social and Economic Sciences https://econpapers.repec.org/paper/sekiacpro/5808261.htm

Bell, Stephanie [April 1998] - The Hierarchy of Money, Working Paper No. 231, The Jerome Levy Economics Institute

Bell, Stephanie [July 1998] - Can Taxes and Bonds Finance Government Spending? Reserve Accounting and Government Finance, Working Paper No. 244, Jerome Levy Economics Institute

Bell Stephanie [Nov 1999] - Functional Finance: What, Why, and How?, Working Paper No. 287

Bell, Stephanie A. and L. Randall Wray [June 2004] - The War on Poverty After 40 Years: A Minskyan Assessment, Public Policy Brief

Boyer-Xambeu, Marie-Thérèse, Ghislain Deleplace, and Lucien Gillard. 1994. Private Money and Public Currencies. New York: M.E. Sharpe.

Connors, Louisa and William Mitchell [Nov. 2013] - Framing Modern Money Theory, Working Paper No. 06-13, Centre of Full Employment and Equity

Cook, R.M. 1958. Speculation on the origins of coinage. Historia. 7:257-62.

Davidson, Paul. 1997. "Can Money Be Neutral Even In The Long Run? Chartalism V.S. Monetarism." Unpublished paper.

Fiebiger, Brett [Nov. 2011] - A Rejoinder to "Modern Money Theory: A Response to Critics", in Modern Monetary Theory: A Debate, Working Paper Series 279

Foley, Duncan. 1989. "Money in Economic Activity." The New Palgrave: Money, edited by John Eatwell,

Forstater, Mathew [July 1999] - Functional Finance and Full Employment: Lessons from Lerner for Today?, Working Paper No. 272, The Jerome Levy Economics Institute

Forstater, Mathew [May 2011] - The Freedom Budget at 45: Functional Finance and Full Employment, Working Paper No. 668

Forstater, Mathew [No date] - Abba Ptachya Lerner: 1903-1982, Working Paper No. 52 
Fullwiler, Scott [Nov. 2009] - What if the Government just Print Money?, Electronic copy available at: http://ssrn.com/abstract=1731625

Fullwiler, Scott [Aug 2010] - Modern Monetary Theory - A Primer on the Operational Realities of the Monetary System, Electronic available at: http://ssrn.com/abstract $=1723198$

Fullwiler, Scott T. [No date] - Setting Interest Rates in the Modern Money Era, Center for Full Employment and Price Stability

Fullwiler, Scott T. and Susan Meyeraan [April 2010] - Confronting Poverty with Jobs and Job Training: A Northeast lowa Case Study

Fullwiler, Scott, Stephanie Kelton, L. Randall Wray [January 2012] - Modern Money Theory: A Response to Critics, in Modern Monetary Theory: A Debate, Working Paper Series 279

Gardiner, Geoffrey W. - The Primacy of Trade Debts in the Development of Money, in Credit and State Theory of Money, 2004

Goodhart, Charles. 1996. "The Two Concepts of Money and The Future of Europe." Unpublished paper.

Henry, John F. - The Social Origins of Money: The Case of Egypt, in Credit and State Theory of Money, 2004

Hudson, Michael - The Archaeology of Money: Debt versus Barter Theories OF Money's Origins, in Credit and State Theory of Money, 2004

Hurford, Peter and Fadhel Kaboub [2012] - The Employer of Last Resort: A Policy to Ensure Full Employment and Greater Price Stability, Department of Economics, Denison University Summer School Project

Ingham, Goeffrey [1996]- "Money is a Social Relation." Review of Social Economy, Vol. LIV, No. 4, pp. 507529.

Ingham, Geoffrey [2004] - The Emergence of Capitalist Credit Money, in Credit and State Theory of Money Ingham, Geoffrey [Sept. 2009] - Notes on Revisiting the Credit Theory of Money, Nanteree

Ingham, G. -2013b. "Revisiting the Credit Theory of Money and Trust," in J. Pixley (ed) (2013). New Perspectives on Emotions in Finance, London: Routledge, 121-139.

Innes, A. Mitchell May 1913 (2004) - "What is Money?" in Wray, Credit and State Theories of Money, Edward Elgar,

Innes, A Mitchell [May 1914] - The Credit Theory of Money, Transcript from: The Banking Law Journal, Vol. 31(1914), Dec./Jan., Pages 151-168

Iwai, Katsuhito [Nov. 1997] - Evolution of Money, The Evolution of Economic Diversity, Routledge, London

Kadmos, George [Jan 2000] - The Taxes-Drive-Money and Employer of Last Resort Approach to Government Policy, Journal of Economics and Social Policy, Vol. 5. Issue 1

Keynes, John Maynard. 1971. The Collected Writings of John Maynard Keynes, Volume V. Donald Moggridge, ed. London, UK and Basingstoke, UK: The MacMillan Press, Ltd.

Keynes, J.M. 1930. A Treatise on Money. New York: Harcourt Brace 
Kiyotaki, N. and R. Wright. 1987. "Acceptability, Means of Payment and Media of Exchange." The New Palgrave: Money, edited by John Eatwell, Murray Milgate, and Peter Newman. New York and London: W.W. Norton, pp. 3-5.

Knapp, Georg Friedrich. 1924. The State Theory of Money. Clifton, NY: Augustus M. Kelley.

Knapp, G.F. 1905. The State Theory of Money. Abridged and trans. By H.E. Batson, London: Routledge and Kegan Paul.

Kraay, C.M. 1964. Hoards, small change and the origin of coinage. Journal of Hellenic Studies. 84:76-91.

Laidler, David. 1987. "Fiat Money." The New Palgrave: Money, edited by John Eatwell, Murray Milgate, and Peter Newman. New York and London: W.W. Norton, pp. 20-21.

Menger, Carl [1892] - On the Origin of Money, Economic Journal, Vol. 2 (1892), pp.239-55, translated by Caroline A. Foley

Lerner, Abba P. [Feb.1943]. "Functional Finance and the Federal Debt." Social Research, Vol. 10, No. 1, February, pp. 38-52.

Lerner, Abba P. 1947. "Money As A Creature Of The State." American Economic Review, Vol. 37, No. 2, pp. 312-317.

Lerner, Abba P. 1951. Economics of Employment, New York: McGraw-Hill.

Minsky, Hyman P. [1986] - Stabilizing an Unstable Economy, Yale University Press, London

Menger, Karl. 1892. "On The Origin of Money." Economic Journal, Vol. 2, No. 6, pp. 239-255.

Minsky, Hyman P. 1986. Stabilizing An Unstable Economy. New Haven: Yale University Press.

Minsky, Hyman P. 1977. "The financial instability hypothesis: an interpretation of Keynes and an alternative to 'standard' theory." Challenge 20(1): 26.

Mitchell, William and Joan Muysken [June 2008] - Full employment abandoned: shifting sands and policy failures, Working Paper No. 08-01, Center of Full Employment and Equity

Mitchell, William [April 2013] - Full Employment Abandoned: The Triumph of Ideology over Evidence, Working Paper No. 13-02

Mosler, Warren [Feb. 1997] -Full Employment AND Price Stability - The Center of the Universe

Murray Milgate, and Peter Newman. New York and London: W.W. Norton, pp. 519-525.

Nersisyan, Yeva and L. Randall Wray [2010] - Deficit Hysteria Redux? Why we should stop worrying about U.S. Government Deficits, Public Policy Brief No. 111, Levy Economics Institute of Bard College

Nersisyan, Yeva and L. Randall Wray [2010] -Does Excessive Sovereign Debt Really Hurt Growth? A Critique of This Time is Different, by Reinhart and Rogoff, Working Paper No. 603, Levy Economics Institute of Bard College

Papadimitriou, Dimitri B. [Oct. 2008] -Promoting Equality through an Employment of Last Resort Policy, Working Paper No. 545, The Levy Economics Institute of Bard College

Quigguin, A. Hingston. - 196?. The Story of Money. New York: Roy Publisher. 
Samuelson, Paul. 1973. Economics. 9th ed. New York, NY: McGraw-Hill. P-274-6

Tcherneva, Pavlina R. [Feb. 2004] - Job or Income Guarantee?, USBIG Discussion Paper No. 79

Tcherneva, Pavlina [July 2005] - The Nature, Origins, and Role of Money: Board and Specific Propositions and Their Implications for Policy Working Paper No. 46, Center for Full Employment and Price Stability

Tcherneva, Pavlina R. [Oct 2011] - Beyond Pump Priming, One Pager No. 16, 25 ${ }^{\mathrm{TH}}$ Anniversary Levy Economics Institute of Bard College

Tcherneva, Pavlina R. [Sept 2012] - Beyond Full Employment: The Employer of Last Resort as an Institution for Change. Working Paper No. 732, Levy Economics of Bard College

Tcherneva, Pavlina R. [March 2014] - Full Employment: The Road not Taken, Working Paper no. 789, Levy Economics Institute of Bard College

Tcherneva, Pavlina R. [Oct 2014] -- Growth for Whom, One Pager No.-47, The Levy Economics Institute of Bard College

Tcherneva, Pavlina R. [2015] - When a Rising Tide Sinks Most boats : Trends in US Income Inequality, Policy Note -2015/4, The Levy Economics Institute of Bard College

Tcherneva, Pavlina R. [March 2016] -- Money Power and Monetary Regimes -Working Paper No. 861, The Levy Economics Institute of Bard College

Tcherneva, Pavlina R. [Aug 2017] -Unemployment: The Silent Epidemic -Working Paper No. 895, The Levy Economics Institute of Bard College

Tcherneva, Pavlina R. -- [April 2018] -- The Job Guarantee: Design, Jobs, and Implementation, Working Paper No. 902 , The Levy Economics Institute of Bard College

Tymoigne, Eric and L. Randall Wray [July 2005] - Money: An Alternative Story, Working Paper No. 45

Tymoigne, Eric [Nov. 2006] - An Inquiry into the Nature of Money: An Alternative to the Functional Approach, Working Paper No. 481, The Levy Economics Institute of Bard College

Tymoigne, Eric and L. Randall Wray [Nov 2013] - Modern Money Theory 101: A Reply to Critics, Working Paper No. 778, The Levy Economics Institute of Bard College

Tymoigne, Eric [March 2014] - Modern Money Theory and Interrelation between the Treasury and the Central Bank: The Case of the United States, Working Paper No. 788, The Levy Economics Institute of Bard College

Éric Tymoigne May 2017, On the Centrality of Redemption: Linking the State and Credit Theories of Money through a Financial Approach to Money, WP 890

Wray, L. Randall. 1990. Money and Credit in Capitalist Economies: The Endogenous Money Approach. Aldershot: Edward Elgar.

Wray, Randall L. [March 1993] - The Origins of Money and the Development of the Modern Financial System, Working Paper No. 86, The Levy Economics Institute of Bard College 
Wray, L. Randall (Nov, 1997). Government as Employer of Last Resort: Full Employment without Inflation, The Jerome Levy Economics Institute, Working Paper No. 213

Wray, Randall L. (June 1998) - Zero Unemployment and Stable Prices, Journal of Economic Issues, Vol. XXXII, No. 2

Wray, Randall L. [Sept. 1998] - Modern Money, Working Paper No. 252, The Jerome Levy Economics Institute

Wray, Randall L. [Sept. 2000] - Money and Inflation, Working Paper No. 12, Center for Full Employment and Price Stability

Wray, Randall L. [Dec. 2001] - Understanding Modern Money, Workshop on Understanding Unemployment in Australia, Japan and the USA: a Cross Country Analysis, Center of Full Employment and Equity

Wray, Randall L.[Aug. 2003] - Currency Sovereignty and the Possibility of Full Employment, Working Paper No. 28, Center for Full Employment and Price Stability

Wray, Randall L. Ed. [2004] - Credit and State Theories of Money: The Contributions of A. Mitchell Innes, Edward Elgar Publishing Ltd

Wray, Randall L. [April 2004] - The Credit Money and State Money Approaches, Working Paper No. 32

Wray, L. Randall (Aug, 2007). The Employer of Last Resort Programme: Could it Work for Developing Countries?, Economic and Labour Market Papers, International Labour Office, Geneva

Wray, Randall L. [Aug. 2007] - A Post-Keynesian View of Central Bank Independence, Policy Targets, and the Rules-versus-Discretion Debate, Working Paper No. 510, Levy Economics Institute of Bard College

Wray, Randall L. [Sept. 2007] - Minsky's Approach to Employment Policy and Poverty: Employer of Last Resort and the War on Poverty, Working Paper No. 515, The Levy Economics Institute

Wray, Randall L. [July 2008] - Macroeconomic Stability, Affordability and Manageability of Employer of Last Resort Programmes, PROOF

Wray, Randall L. [Oct. 2009] - An Alternative View of Finance, Saving, Deficits, and Liquidity, Working Paper No. 580, The Levy Economics Institute of Bard College

Wray, Randall L. [Jan. 2010] - Alternative Approaches to Money, Theoretical Inquiries in Law, Vol. 11, No. 1 , Article 3

Wray, Randall L. [Dec. 2010] - Money, Working Paper No. 647, The Levy Economics Institute of Bard College

Wray, L. Randall (May 2012). Introduction to an Alternative History of Money, Levy Economics Institute, Working Paper No. 717

Wray, Randall L. [Oct. 2012] - Modern Money: The Way a sovereign currency "works"

Wray, L. Randall (Nov. 2012). A Meme for Money, WP-736, Levy Economics Institute.

Wray, Randall L. (An Interview by Travis Strawn) [Dec. 2013] - The Failure of Orthodox Economics: An Interview with Randall Wray 
Wray, Randall L. [2014?] - The Credit Money, State Money, and Endogenous Money Approaches: A Survey and Attempted Integration

Wray, L. Randall (March 2014). From the State Theory of Money to Modern Money Theory: An Alternative to Economics Orthodoxy, Working Paper No. 792, Levy Economics Institute of Bard College.

Wray, L. Randall (March 2014).-Central Bank Independence: Myth and Misunderstanding, WP 791

Wray, 14 May 2014, Do we need taxes? The MMT perspective

Wray, Randall L. [15 May 2014] - What are Taxes For? The MMT Approach

Wray, Randall L. [May 2014] - Forget Taxes for Redistribution: What to do About Inequality

Wray, 02 June 2014, Taxes and the Public Purpose

Wray, 17 June 2014, Tax Bads, Not Goods

Wray, Randall L. [June 2014] - Modern Money Theory: The Basics,

Wray, Randall L. [Dec. 2014] - The Answer to the Unemployment Problem is More Jobs

Wray, L. Randall [2015] - Introduction: The Basics of Modern Money Theory, in Modern Money Theory

Wray, Randall L. [2015] - Modern Money Theory: A Primer on Macroeconomics for Sovereign Monetary System

Wray, Randall [Nov. 2016] - Taxes are for Redemption Not Spending, World Economic Review

Wray, Randall L. and Flavia Dantas [2017] - Full Employment - Are We There Yet, The Levy Economics Institute of Bard College

Wray, Randall L., Stephanie A. Kelton, Pavlina R. Tcherneva, Scott Fullwiler, and Flavia Dantas [2018] Guaranteed Jobs through a Public Service Employment Program, Policy Note, 2018/2, Levy Economics Institute of Bard College

Wray, Randall L. [Jan 2018] - Functional Finance: A Comparison of the Evolution of the Positions of Hyman Minsky and Abba Lerner, Working Paper No. 900, Levy Economics Institute and Bard College]

Wray, Randall L. [No Date] - Review of: Full Employment Abandoned: Shifting Sands and Policy Failures, by William Mitchell and Joan Muysken

Wray, Randall L. [No date] - Understanding Modern Money: How a sovereign currency works, in the book 'New Approaches to Monetary Theory: Interdisciplinary Perspective", edited by Heiner Ganssmann, Routledge

Wray, Randall L. [No date] - MMT as an Alternative to Austerity

Wray, Randall L.[No date] - Monetary Policy: An Institutionalist Approach, Working Paper No. 21

Wray, Randall L.[No date] - A Monetary and Fiscal Framework for Economic Stability: A Friedmanian Approach to Restoring Growth, Working Paper No. 22

Wray, Randall L. [No date] - Is Keynesian Institutionalist? An Irreverent Overview of the History of Money from the Beginning of Beginning to the Present, Working Paper No. 252, The Jerome Levy Economics Institute 
Wray, Randall L. [No date] - Endogenous Money Approach, Working Paper No. 17

Wray, L. Randall and Stephanie Bell [No date] - Introduction to Credit and State Theories of Money, Downloaded from Elgar Online via free access 